IZA DP No. 8188

How to Stimulate Single Mothers on Welfare to Find a Job: Evidence from a Natural Experiment

Marike Knoef

Jan C. van Ours

May 2014 


\title{
How to Stimulate Single Mothers on Welfare to Find a Job: Evidence from a Natural Experiment
}

\author{
Marike Knoef \\ Leiden University \\ Jan C. van Ours \\ CentER, Tilburg University, \\ University of Melbourne, CEPR, CESifo and IZA
}

\author{
Discussion Paper No. 8188 \\ May 2014
}

IZA

P.O. Box 7240

53072 Bonn

Germany

\author{
Phone: +49-228-3894-0 \\ Fax: +49-228-3894-180 \\ E-mail: iza@iza.org
}

\begin{abstract}
Any opinions expressed here are those of the author(s) and not those of IZA. Research published in this series may include views on policy, but the institute itself takes no institutional policy positions. The IZA research network is committed to the IZA Guiding Principles of Research Integrity.

The Institute for the Study of Labor (IZA) in Bonn is a local and virtual international research center and a place of communication between science, politics and business. IZA is an independent nonprofit organization supported by Deutsche Post Foundation. The center is associated with the University of Bonn and offers a stimulating research environment through its international network, workshops and conferences, data service, project support, research visits and doctoral program. IZA engages in (i) original and internationally competitive research in all fields of labor economics, (ii) development of policy concepts, and (iii) dissemination of research results and concepts to the interested public.
\end{abstract}

IZA Discussion Papers often represent preliminary work and are circulated to encourage discussion. Citation of such a paper should account for its provisional character. A revised version may be available directly from the author. 


\section{ABSTRACT}

\section{How to Stimulate Single Mothers on Welfare to Find a Job: Evidence from a Natural Experiment ${ }^{*}$}

We present the results from a natural experiment in which single mothers on welfare were stimulated to find a job. Two policy instruments were introduced: an earnings disregard and job creation. The experiment was performed at the level of municipalities in The Netherlands, a country with relatively high benefits and low incentives for single mothers to leave welfare for work. In our analysis, we make a distinction between native and immigrant welfare recipients. For immigrant single mothers and some groups of native single mothers we find a positive employment effect of an earnings disregard. Job creation in addition to the earnings disregard increased working hours for some groups of single mothers. Although the outflow from welfare was not affected, welfare expenditures were reduced.

JEL Classification: C41, C93, I38, J64

Keywords: welfare, single mothers, natural experiment

Corresponding author:

Jan C. van Ours

Tilburg University

P.O. Box 90153

5000 LE Tilburg

The Netherlands

E-mail: vanours@uvt.nl

\footnotetext{
* The authors thank the Ministry of Social Affairs and Employment, CentERdata, and Stichting Instituut GAK for financial support. Furthermore, we thank the Dutch municipalities for their cooperation with the data collection and Henri de Groot, Stephen Jenkins, Pierre Koning, Jorna Leenheer, Konstantinos Tatsiramos, Bas van der Klaauw, and participants of the ESPE conference 2012, EEA conference 2012, IZA/OECD/World Bank Conference on Safety Nets and Benefit Dependence 2013, Banco de Portugal Labor Market Conference 2013, and the EALE conference 2013 as well as seminar participants at Tilburg University and Humboldt University Berlin for useful comments. The data used were made available by Statistics Netherlands through their remote access facility.
} 


\section{Introduction}

In the past decades political and public attitudes towards welfare recipients have changed. Welfare recipients including single mothers with young children are encouraged to find a job. It is, however, particularly difficult to bring these single mothers back to work as they have to combine work and childcare and often for them the financial incentives to go to work are not very strong. ${ }^{1}$ Usually, benefits are reduced one-for-one when a welfare recipient starts earning. Making work pay policies have been introduced to strengthen financial incentives to employment, through in-work benefits, earnings disregards or reemployment bonuses. In-work benefits are provided conditional on the recipient having a job. Earnings disregards imply that welfare benefits are withdrawn less than one-for-one with earnings. Reemployment bonuses are provided to unemployed individuals who find a job. ${ }^{2}$

In-work benefits are popular. In 2007, half of the OECD countries had some form of inwork benefit policy (Immervoll and Pearson, 2009). In the U.S. the Earned Income Tax Credit (EITC) is a financial incentive program to encourage work among low-income families with children by providing refundable tax credits or earnings subsidies. Several studies find that the increased generosity of the EITC as from 1987 had large effects on employment rates (Eissa and Liebman, 1996, Ellwood, 2000, Meyer and Rosenbaum, 2001, and Hotz et al., 2001). Financial incentives, however, worked almost exclusively through the participation margin, while single mothers were rather unresponsive on the intensive margin (Meyer, 2002). Not all previous U.S. studies find positive effects of financial incentives on single mothers labor supply. Following a welfare reform in 1996, Matsudaira and Blank (2013) analyze the impact of changes in earnings disregards (in addition to the EITC, that operates through the tax system). They exploit state differences in the level of the earnings disregards and find that the changes had little effect on labor supply or income because only few women used these earnings disregards.

An important 'making work pay' policy in the UK is the Working Families Tax Credit (WFTC). This program, which was introduced in 1999, provides support for low wage working families. An important difference with the EITC is that the WFTC has a minimum weekly hours eligibility condition. ${ }^{3}$ At the introduction of the less generous predecessor of the WFTC (the Family Credit) the minimum hours cut-off was set at 24 hours. In 1992 this was reduced to

\footnotetext{
${ }^{1}$ A large empirical literature has studied labor supply responses to taxes, transfers and active labor market policies. See, for example, Blundell and Macurdy (1999) and Heckman et al. (1999) for an overview.

${ }^{2}$ Alternatively, programs of direct job creation and wage subsidies may have a positive effect on employment at the lower end of the labor market. However, participation in subsidized jobs may stigmatize and reduce chances of finding a regular job (Boeri, 1997). Martin and Grubb (2001) provide an overview of evaluation findings in OECD countries and conclude that subsidized jobs do not help the unemployed to get permanent jobs. Kluve (2010) presents a meta-analysis of 137 ALMP evaluation studies in Europe. He finds that direct employment programs in the public sector are rarely effective and frequently detrimental for the employment prospects of participants.

${ }^{3} \mathrm{~A}$ description and comparison of the EITC and WFTC program can be found in Brewer (2001).
} 
16 hours and this encouraged a significant fraction of inactive single mothers into work (Blundell and Hoynes, 2004). At the introduction of the WFTC in 1999 financial incentives increased, particularly for single mothers with young children. Among others, Brewer et al. (2007) find that the WFTC induced single mothers to increase their participation in the labor market by $5 \%$-points.

For the Netherlands, Bettendorf et al. (2013) studied the extension of an earned income tax credit for mothers with their youngest child between 12 and 15 years. They find a negligible effect on the labor force participation and argue that this is probably because they use as the control group single mothers with children younger than 12 or older than 15 years of age. When they use as control group single women without children as is done in most related studies they also find a positive effect of the financial incentive. In the case of Bettendorf et al. (2013) single women without children are an invalid control group, which is in line with the critique of Blundell and Macurdy (1999) and Meghir and Philips (2010). In our paper we will therefore also use single mothers as a control group, instead of single women without children.

Financial incentives were also investigated in Canada, where the self-sufficiency project experimented with a generous time-limited earnings supplement available to single parents who had been on welfare for at least a year, and who subsequently left welfare and found full-time work (defined as at least 30 hours a week). Results show positive effects in the short run (Michalopoulos et al., 2005), but, temporary wage subsidies did not have a long run effect on wages and welfare participation (Card and Hyslop, 2005).

Reemployment bonuses create direct financial incentives to find and accept a job. On the basis of outcomes from four U.S. cash bonus experiments and six job search experiments Meyer (1995) concludes that economic incentives affect the speed by which unemployed workers leave the unemployment insurance rolls. Nevertheless, empirical studies on reemployment bonuses usually show modest effects on the behavior of the unemployed workers who could benefit from such bonuses (see Woodbury and Spiegelman, 1987, Anderson, 1992, Decker and O'Leary, 1995, O'Leary et al., 2005 and Van der Klaauw and van Ours, 2013).

Several US studies report that welfare reforms had a greater effect on black single mother's employment than on white single mother's employment (McKernan et al., 2000, O'Neill and Hill, 2001, and Noonan et al., 2007). This differential impact is attributed especially to differences in educational attainment among black and white immigrants and to different familial circumstances. Black single mothers are more often never married. This increases their economic vulnerability, which may make them more open to work requirements. However, even after controlling for these differences, Noonan et al. (2007) found that changes in welfare policies and labor market conditions affected black single mothers' employment more than white single mothers' employment. 
Our paper contributes to the literature on how to bring welfare recipients to work. We present the results of a natural experiment for single mother welfare recipients in the Netherlands. Previous studies on financial incentives for single mothers' welfare recipients have been focusing on the U.S. and the U.K., which are both countries with relatively low benefits. The Dutch labor market is interesting to study as it is a representative of countries with high benefits and low incentives for single mothers to make a transition from welfare to work. Until 2009 Dutch single mothers on welfare had no financial incentives to work in small part-time jobs. When a single mother started to earn money, her welfare benefits were reduced one for one. Therefore, she was financially tempted to enter the labor market only if she could earn at least the amount of the welfare benefit. However, single mothers on welfare are often low skilled and therefore have a low earnings capacity. A minimum wage single mother can only escape welfare when she works at least about 30 hours per week. This is a difficult task in combination with childcare responsibilities and is often not in accordance with the assumptions of these mothers about motherhood. The Dutch government intended to make part-time work financially more attractive and possibly reduce poverty among single mothers. A natural experiment was set-up to explore the potential of two policy measures; an earnings disregard and direct job creation. As we will describe in more detail below, the earnings disregard was introduced to persuade single mothers to accept part-time jobs. The experiment took place in 2009 and 2010 and was focused on single mothers on welfare with at least one child younger than 12 years. In the experiment 14 Dutch municipalities implemented the earnings disregard while 6 of them also implemented direct job creation. Our paper evaluates the instruments using a difference-indifference-in-differences approach in which we simultaneously compare (1) the period before and during the experiment, (2) the municipalities with and without the experimental policy instruments, and (3) single mothers with at least one child younger than twelve years and single mothers with all children twelve years and older. Furthermore, because of the difference in labor market situation we make a distinction between native and immigrant single mothers.

Our empirical analysis proceeds in three steps. First, we investigate the total effect of the policy experiments. Then, we proceed by investigating the distinct effects of the earnings disregard and of job creation on top of the earnings disregard. Finally, as in Blundell et al. (2009), we make a distinction between two types of treated single mothers depending on the age of their youngest child. Since the compulsory education requirement for children starts at the age of 5 , we distinguish single mothers with the youngest child in the age category $0-4$ years from those with the youngest child 5-11 years. Our main finding is that for immigrant single mothers there was a positive employment effect of an earnings disregard. Job creation increased working hours for immigrant single mothers with the youngest child between the age of 5 and 11 and for native single mothers with the youngest child between 0 and 4 years. Although the 
outflow from welfare is not affected, welfare expenditures go down. For native single mothers we find smaller treatment effects than for immigrant single mothers.

The set-up of our paper is as follows. Section 2 shortly explains the Dutch welfare system and describes the natural experiment. Section 3 describes the data and section 4 presents some exploratory analysis. The empirical analysis is presented in section 5. Section 6 concludes.

\section{Natural experiment}

\subsection{Welfare in the Netherlands}

In the Netherlands welfare benefits guarantee a minimum income for all unemployed or parttime employed workers. Welfare benefits are means-tested and a single mother can only qualify if she does not have sufficient earnings, alimony or other benefits, like unemployment insurance benefits or disability insurance benefits. Welfare recipients have to comply with job search requirements. Furthermore, eligibility for welfare depends on wealth. Single renters may own at most 5.5 thousand euro and homeowners only qualify for welfare when they own not more than 46 thousand euro. Welfare benefit levels are set by the central government in January and July of each year. During the experiment, the welfare benefit level net of taxes was about $€ 900$ for single mothers between the age of 21 and 65 and $€ 480$ for single mothers younger than 21 . In addition, people may receive allowances up to some maximum amounts. Welfare benefits are provided by municipalities.

At the start of the experiment about 300,000 individuals in the Netherlands received welfare benefits (about $2.7 \%$ of all persons between the age of 15 and 65 ). Of these, a substantial $26 \%$ were lone parents, predominantly single mothers. About $10.6 \%$ of all single parents depend on welfare (Statistics Netherlands, 2011). This makes single mothers an important group to investigate.

\subsection{Set-up of the experiment}

In the experiment two policy instruments were introduced, an earnings disregard of $€ 4$ for each hour worked, up to $€ 120$ net per month and direct job creation in the public and private sector.

The first policy instrument, the earnings disregard, encouraged single mothers to participate in paid employment by allowing them to earn income while they were receiving financial assistance. In the experiment $€ 4$ per hour worked were exempted as income when determining the monthly welfare benefits. So, for every hour that a single mothers worked, she received $€ 4$, up to a maximum of $€ 120$ per month. ${ }^{4}$ Without this instrument, welfare benefits would have

\footnotetext{
${ }^{4}$ As a point of reference, in January 2011 the gross legal minimum wage was $€ 1424$ per month, for employees as from the age of 23 who worked full-time (36, 38, or 40 hours per week, depending on the sector of employment). This means a net wage of about $€ 1150$ and a net hourly wage of about $€ 7.50$.
} 
been reduced by the full amount of the earnings. ${ }^{5}$ Single mothers on welfare who were already participating in the labor market before the start of the experiment were also eligible for the earnings disregard during the treatment period. Therefore, there was no reason to postpone labor force participation and we do not have to worry about anticipation effects. The aim of the earnings disregard was to increase labor force participation if only through a part-time job. By entering the labor market on a part-time basis the women might find it easier to expand their working hours later on in life.

Figure 1 illustrates how in a labor supply framework, the earnings disregard affects financial incentives in case a single mother could earn the hourly minimum wage of (approximately) $€ 7.50$ and receives welfare benefits of $€ 225$ per week. In this situation a minimum wage job of 30 hours per week would generate the same income as welfare benefits would. The budget constraint for a welfare recipient is BCA and maximum utility would be derived at point $\mathrm{B}$, where the welfare recipient does not participate in the labor market. If an earnings disregard is introduced the new budget constraint is BDECA. ${ }^{6}$ The maximum earnings disregard on a weekly basis would be after 7.5 hours at point D. Figure 1 indicates that a welfare recipient might reach a higher utility in point $\mathrm{D}$ or perhaps slightly right of point $\mathrm{D}$. It does not seem very likely that the welfare recipient would find a full-time job more attractive because of the earnings disregard. However, this was not the main aim of the experiment. In the example of a minimum wage earner, there is even a disincentive to work between 30 and 34 hours per week because in that case the single mother looses her welfare benefits and her income drops. So, for some single mothers the outflow from welfare may diminish because of the design of the experiment. Because the earnings disregard makes it more attractive to be on welfare, the experiment may encourage single mothers with young children to enter welfare. In the analysis below we explore whether such an entitlement effect exists.

The second policy instrument is direct job creation in the public and private sector through a so called 'labor pool'. Municipalities would search jobs for single mothers for at least 12 hours per week. Single mothers in the labor pool work for a regular employer or for the municipality itself, and the jobs may be subsidized if the earnings capacity of the single mother is low. Those who obtained a job through the job creation scheme were also eligible for the earnings disregard. When analyzing direct job creation we analyze an intention to treat, since the results are based on the initial treatment assignment and not on the treatment effect for people who actually took the treatment and participated in the labor pool. The intention-to-treat effect does not suffer

\footnotetext{
${ }^{5}$ Due to decentralization municipalities may apply different policies to bring people on welfare back to work. An earnings disregard in this form, however, had no legal basis. This was only allowed for the treatment group in the treatment municipalities during the treatment period.

${ }^{6}$ Figure 1 does not take into account the possible costs of formal child care. However, when single mothers on welfare use formal child care to be able to work they receive a generous subsidy from the tax authority and the municipality.
} 
from a nonrandom assignment of jobs to single mothers eligible for direct job creation. Also, using an intent-to-treat analysis we analyze how direct job creation works in a realistic context, which explicitly acknowledges the success or failure that municipalities experience in finding jobs for single mothers on welfare. A disadvantage of the intent-to-treat design is that we may underestimate the potential effectiveness of job creation, for example, in case municipalities do not succeed in finding jobs for single mothers on welfare.

Fourteen Dutch municipalities participated in the experiment (the treatment municipalities). ${ }^{7}$ All of them applied the earnings disregard to the treatment group, i.e. all single mothers on welfare with a least one child below the age of 12 . Six of these fourteen municipalities also applied direct job creation. We exploit this variation to identify the effect of direct job creation on top of the earnings disregard. ${ }^{8}$ The control group consists of single mothers with children between the age of 12 and 18 while all other Dutch municipalities form the control municipalities. ${ }^{9}$ In the robustness checks we will narrow the sample around the age eligibility threshold of 12. The earnings disregard was announced and implemented at the start of the year 2009 in all treatment municipalities. The implementation of direct job creation took somewhat longer and started in January 2010 for most of the municipalities (in the estimation we take into account timing differences across municipalities). The experiment ended at the end of December 2010. We have also data of the years 2005-2008 available, which form the control period.

The treatment municipalities are of different size and are geographically spread through the Netherlands. It is possible that single mothers selected themselves into treatment municipalities. However, this is not very likely since single mothers did not know in advance which municipalities would participate in the experiment. And, we do not observe movements of welfare recipients to treatment municipalities. Municipalities were not forced to participate in the experiment. Instead, municipalities got the opportunity to apply for the experiment and if they participated they had to implement the instruments, for which they received a financial compensation. The advantage of voluntary participation is that the participating municipalities were capable to implement the instruments and deliver data that are needed to evaluate the experiment. A possible drawback of voluntary participation is that a selection bias is in-

\footnotetext{
${ }^{7}$ These are Almere, Bodegraven, Breda, Echt-Susteren, Enschede, Groningen, Heerenveen, Nijmegen, Reiderland, Schiedam, Scheemda, Vlaardingen, Winschoten, and Zwolle.

${ }^{8}$ During the period of analysis also reemployment bonuses were introduced in the treatment municipalities. Single mothers on welfare could receive a reemployment bonus of $€ 500$ when they left welfare for at least six months because of working enough hours in the labor market to be financially independent. In some municipalities reemployment bonuses were already implemented before the experiment and part of the municipalities that did not participate in the natural experiment also provided reemployment bonuses. We have no information about which control municipalities provided reemployment bonuses and therefore we cannot identify the effect of the reemployment bonus using the difference-in-differences approach. In the estimation we correct for the fact that in some treatment municipalities the control group was entitled to a reemployment bonus and that in some municipalities the treatment group was already entitled to a reemployment bonus in the treatment period.

${ }^{9}$ January 1, 2009 The Netherlands had 441 municipalities. The results hardly change when we leave out the four largest municipalities (Amsterdam, Rotterdam, The Hague, and Utrecht).
} 
troduced if in particular motivated municipalities participate, who perform already relatively good in terms of bringing single mother welfare recipients back to work quickly. It could also be that participating municipalities have relatively underprivileged single mothers. By using a triple difference approach we correct for a priori differences between treatment and control municipalities. We will see later that observed characteristics of single mothers in the treatment and control municipalities are about the same and that the growth rates of the inflow into welfare are similar in treatment and control municipalities. Furthermore, we find that before the experiment job finding rates and the outflow from welfare were similar in treatment and control municipalities.

A final concern is that increased labor market participation of the treatment group would crowd out participation of single mothers in the control group. Then, we would overestimate the effect of the instruments. However, since single mothers are only a small group in the total population of job seekers we do not consider this to be problematic. ${ }^{10}$

\section{Data}

Our data are from the 2005-2010 statistics on welfare benefits (BUS, Bijstandsuitkeringenstatistiek, CBS 2010a) gathered by Statistics Netherlands. The BUS is an administrative dataset that contains all welfare recipients in the Netherlands and provides information about gender, age, the cause of the welfare benefits, whether welfare recipients receive income from other resources (like labor income or alimony), the amount of welfare benefits that they receive, and whether or not they are a homeowner. We also have information about the number of children, age of the children, marital status and the ethnicity for all welfare recipients between 2005-2010 based on the population register.

In this study we select all Dutch municipalities except Amsterdam and Langedijk. Amsterdam and Langedijk participated in the experiment, but the implementation of the experimental instruments failed in these municipalities, such that they did not provide reliable information about the effects of the instruments. Furthermore, we select all single mothers that flowed into welfare as from January 12005 . Figure 2 shows the yearly inflow of single mothers in welfare for the treatment group and the control group in the treatment and control municipalities. Clearly, there are differences between the treatment and control group, but within these groups the differences between treatment and control municipalities are small. For the control group relatively a lot of welfare spells started in 2009 and 2010, probably as a result of the financial and economic crisis. The number of new spells in the treatment group declined a bit between 2005 and 2008, but increased thereafter. Note that the growth rate in 2009 and 2010 is about the same for the treatment and control municipalities. This indicates that the experiment has

\footnotetext{
${ }^{10}$ As mentioned before, single mothers (treatment + control group) comprise about $25 \%$ of all welfare recipients.
} 
not attracted more single mothers with young children into welfare. ${ }^{11}$

Table 1 shows the number of spells we observe for each single mother in the treatment and control group. In total we observe 72,814 welfare spells for 63,058 single mothers. About $12 \%$ of the welfare spells are from a treatment municipality and the treatment group is about six times larger than the control group. For most of the single mothers (86\%) we just observe one spell, for $12 \%$ of the single mothers we observe two spells, and for the remaining $2 \%$ we observe three spells or more. The characteristics of the single mothers on welfare are presented in table 2, where we compare the treatment and the control group, for the treatment and control municipalities, and for the treatment and control period. The descriptives show that the average age of the single mothers is 34 in the treatment group and 41 in the control group (most single mothers are aged between 20 and 53 years). On average, single mothers in the treatment group have 1.9 children and in the control group 1.7. The youngest child is on average 4.4 years old in the treatment group, and 13.9 years old in the control group. The treatment group consists of a lot of unmarried single mothers, while the control group has relatively more divorced mothers. Between 2005-2008 and 2009-2010 the number of divorced single mothers increased, while the number of married mothers decreased. However, all mothers that we study are living single. A relative large share of $32 \%$ of the single mothers is first generation nonwestern immigrant. Labor force participation is more than $20 \%$ and is somewhat lower in the treatment municipalities than in the control municipalities. Alimonies are received by $16 \%$ of the single mothers and the share of homeowners is low (3.3\%).

\section{Exploratory analysis}

To establish the effectiveness of the policy instruments we observe five variables of interest. Two of them relate to durations, i.e. the duration from the start of the welfare spell to the acceptance of a part-time job while still remaining in welfare and the duration from the start of the welfare spell until outflow from welfare occurs. The other three variables of interest are financial variables, i.e. earnings received by the single mothers, welfare benefits paid by the municipalities, and the sum of earnings and welfare benefits. The variables of interest are only defined for welfare recipients. We do not have data about all single mothers in the Netherlands and this would be a problem when the decision to take up welfare is a function of benefit generosity. However, as discussed before, Figure 2 shows that the experiment did not attract more single mothers with young children into welfare. In the remainder of this section we explore the variables of interest, where we separately consider immigrant single mothers

\footnotetext{
${ }^{11}$ When we regress the growth rates of the treatment group for the control and treatment municipalities on year dummies, an indicator for the treatment municipalities and interaction terms of the indicator and the year dummies we find no significant difference in the growth rates between treatment and control municipalities.
} 
which we define as non-Western immigrants and native single mothers which we define as native Dutch or Western immigrants. Immigrant single mothers may have language difficulties and may be influenced by their home-country culture regarding the upbringing of children (Fernandez, 2007; Kok et al., 2011). This may influence their labor force participation and their response to the policy instruments. Furthermore, compared to natives, immigrant single mothers relatively often bring up their children alone as from birth i.e. without the help of a father, a grandmother, or a grandfather. By way of exploratory analysis we consider the total treatment effect by comparing the treatment group to the control group, treatment municipalities to control municipalities, and the treatment period to the control period. In the exploratory analysis we investigate the total effect of the earnings disregard and direct job creation and we ignore the potential heterogeneity of the treatment group.

\subsection{Duration indicators}

The earnings disregard and direct job creation may increase the inflow of single mothers to a part-time job. The solid lines in figure $3 \mathrm{a}$ and $3 \mathrm{~b}$ present the inflow to part-time work for immigrant single mothers in the treatment and the control group. At $t=0$ a welfare spell starts and the graphs show the share of immigrant single mothers that started a part-time job over the duration of their welfare benefit spell.

The two thin solid lines in figure 3a show that in the control period the inflow into parttime work was about the same in treatment and control municipalities. This suggests that the treatment and control municipalities were comparable before the start of the experiment. Within 730 days after the start of a welfare spell almost $20 \%$ of the single mothers started part-time work. The thin and thick grey solid lines in figure 3a show that in the control municipalities the inflow to part-time work is lower in the treatment period than in the control period (probably related to the slowdown in economic activity due to the Great Recession). This decline is represented by the first difference (grey dashed line), which lies below zero because of the negative difference between the treatment and control period. Meanwhile, despite the economic crisis, the inflow into part-time jobs increased for the treatment municipalities (the thin and thick black solid lines). This can also be seen by the positive first difference (the black dashed line). Since we have no reason to assume that single mothers in the treatment municipalities are not influenced by the crisis, this indicates a positive effect of the experiment on the inflow to part-time work.

Figure $3 \mathrm{~b}$ shows the same graph for the control group. As expected, because of the economic crisis, we find that the inflow to part-time work declined in both treatment and control municipalities. This results in negative first differences (the dashed lines are below zero). In figure $3 \mathrm{c}$ we plot the double differences - between the treatment period and the control period 
and between the treatment group and the control group - for the control municipalities and for the treatment municipalities. For example, the black solid line in figure 3c, that represents the double difference (dif2) of the treatment municipalities, shows the difference between the black dashed lines in figure $3 \mathrm{a}$ and $3 \mathrm{~b}$. This line illustrates that in the treatment municipalities the increase in the inflow to part-time work within two years after the start of the welfare benefit was $23 \%$ higher in the treatment than in the control group. The line that represents the double difference of the control municipalities is almost zero (the solid grey line), indicating that there are no large differences between the treatment and the control group in the control municipalities. The triple differences, computed by taking the difference between the two double differences, is clearly positive indicating a positive treatment effect. Using the triple difference approach we take into account that the business cycle may have had a different effect on the treatment and the control group, and we exclude the possibility that the results are the consequences of municipality-specific developments (e.g. that treatment municipalities are less affected by the crisis than control municipalities).

Figure 3d presents the triple differences for natives and shows that there is hardly any treatment effect. ${ }^{12}$ When interpreting the graphs in figure 3 we have to take into account that not all single mothers received the treatment as from the start of their welfare spell. In addition, the sample becomes more and more selective over the welfare duration with regard to observed and unobserved characteristics. In the empirical analysis below we will take this into account.

Panel a of table 3 is set-up in the same way as figure 3. It collects the results of the graphs in figure 3 after a welfare spell of 2 years and shows how the triple difference estimates of the treatment effect after a welfare spell of 2 years can be calculated. The left part of panel a is about immigrant single mothers. In the control municipalities there is almost no difference between the evolution of the treatment group and control group in the share of single mothers finding a part-time job within 2 years. The double difference is equal to 0.04. For the treatment municipalities there is a substantial difference. Whereas the control group faces a decline of 0.19 , the treatment group faces an increase of 0.04 , leading to a double difference of 0.23 . In combination with the double difference for the control municipalities of 0.04 this leads to a triple difference of 0.19 , i.e. a triple difference of 19 percentage-points (this is also what we see in figure 3c after two years). The right-hand side part of table $3 \mathrm{a}$ shows that for native single mothers the triple difference estimates of the treatment effects are small. Here the triple difference is only -0.01 .

The second duration indicator from which the effectiveness of the treatment may be derived is the duration of the welfare spell. In the long run, the policy instruments may strengthen mother's labor force attachment and increase their probability to flow out of welfare. However,

\footnotetext{
${ }^{12}$ Inflow curves and first differences for native single mothers can be found in appendix A.
} 
in the short run direct job creation may have a lock-in effect and the earnings disregard may be so attractive that outflow from welfare becomes less attractive. In the data we have information about total outflow from welfare. We do not know whether people flow out of welfare because of a job or because of other reasons such as finding a partner. Therefore, given our differencein-differences approach, we assume that outflow because of reasons other than work are not influenced by the experiment. Figure $4 \mathrm{a}$ shows that during the control period $31 \%$ of the single mothers in the treatment group left welfare within one year after the start of a welfare spell. After two years this was $54 \%$, and after three years this was about $63 \%$. Just as in figure 3 , we compute first, double, and triple differences. Figure $4 \mathrm{c}$ shows that the triple differences are small indicating a small treatment effect. Figure $4 \mathrm{~d}$ shows that by and large the triple difference results for natives are very much the same. Outflow curves and first differences for natives can again be found in Appendix A.

Panel $\mathrm{b}$ of table 3 collects the results of the graphs in figure 4 and shows us triple difference estimates of the treatment effects after two years in welfare. The treatment effect is $2 \%$-points for immigrants and 5\%-points for natives. The treatment effects are small or perhaps even absent. Apparently, there is no lock-in effect.

\subsection{Financial indicators}

The remaining three indicators of the success of the treatment relate to financial variables. By investigating labor earnings we examine whether the instruments increased the inflow to part-time work and/or whether they increased the number of working hours. Furthermore, we evaluate whether the instruments reduced the welfare benefits paid by the municipalities and whether the instruments reduced poverty among single mothers and their children.

Figure 5 shows the distribution of income from sources other than welfare during the experiment. Mostly, these are earnings, alimonies from ex-partners, and tax reductions. Unfortunately, we can not distinguish earnings from other income that single mothers receive in addition to welfare. However, using the difference-in-differences approach, we can reasonably assume that other income, like alimonies, are not influenced by the experiment and in the remainder of this paper we will therefore define income from others sources as earnings. When income from other resources than welfare exceed the welfare benefit level people have to leave welfare. Extreme income levels in figure 5 are probably related to post-payments.

Panel c of table 3 indicates that earnings increased as a result of the policy instruments, using the same triple difference set-up as before. For immigrant single mothers the triple difference estimate of the treatment effect on earnings is $€ 41$ per month, while for native single mothers it is $€ 8$ per month. Panel d of table 3 shows that for immigrant single mothers welfare benefits on average went down with about $€ 30$ per month because of the experiment. For native single 
mothers this was only $€ 9$ per month. Finally, panel e shows that the net benefits for the single mothers are low; for immigrant mothers it is about $€ 10$ per month, for native mothers it is almost zero.

\section{Empirical analysis}

\section{$5.1 \quad$ Model}

In addition to the exploratory analysis, we present model estimates that take into account background characteristics and unobserved heterogeneity. In this way we allow for changing compositions of the treated and non-treated single mothers that may affect the outcome variables. To identify the effect of the experiment we use three dimensions, (1) we compare the treatment and the control group, (2) we compare treatment and control municipalities, and (3) we compare the treatment period 2009-2010 and the control period 2005-2008. We combine these dimensions using the difference-in-difference-in-differences approach. ${ }^{13}$.

The advantage of the triple difference approach compared to the double difference approach is twofold. First, when developments are different for the treatment and the control group for other reasons than the policy experiment we take this into account by comparing the developments in the control municipalities. Second, when developments are different for the treatment and control municipalities because of other reasons than the policy experiment we take this into account by comparing the control group in the treatment and control municipalities. Using the triple difference approach we assume that there is no contemporaneous shock that affects the relative outcomes of the treatment group in the treatment municipalities during the treatment period. Furthermore, we assume that developments for the control group and developments for the treatment group in the control municipalities are not influenced by the experiment. Figures $3 \mathrm{a}$ and $4 \mathrm{a}$ show that before the experiment inflow into a part-time job and outflow from welfare were very comparable in the treatment and control municipalities. To test the validity of the results section 5.5 also discusses the outcomes of placebo tests in which we use fake treatment years and fake treatment municipalities.

The determinants of the inflow into part-time work and the outflow from welfare are established using a hazard rate model in which the transition rate of individual $i$ at duration $t$ conditional on observed characteristics $X$, unobserved characteristics $u$ and treatment variables function $D \gamma$ is specified as follows:

$$
\theta\left(t \mid X_{i t}, D_{i t}, u_{i}\right)=u_{i} \lambda(t) \exp \left(X_{i t} \beta+D_{i t} \gamma\right)
$$

\footnotetext{
${ }^{13}$ This approach is, amongst others, also used by Gruber (1994), Hamermesh and Trejo (2000) and Campolieti (2004).
} 
where $\beta$ is a parameter vector and $\lambda(t)$ a piecewise constant function representing the pattern of duration dependence. We assume unobserved heterogeneity $u$ to follow a Gamma distribution with variance $\alpha$.

The vector $X$ contains control variables such as the age of the single mother, the age of the youngest child, the number of children, marital status, the cause of the welfare benefits, whether the single mother receives alimony, and whether the single mother is a homeowner. In addition, $X$ contains year dummies, dummies for the treatment municipalities, and dummy variables to correct for the presence of a reemployment bonus in some treatment municipalities ${ }^{14}$.

The treatment variables function $D \gamma$ is specified as follows:

$$
D_{i t} \gamma=\gamma_{1} G_{i t}+\gamma_{2} T_{t}+\gamma_{3} M_{i} \cdot G_{i t}+\gamma_{4} M_{i} \cdot T_{t}+\gamma_{5} G_{i t} \cdot T_{t}+\delta G_{i t} \cdot M_{i} \cdot T_{t}
$$

where $G$ represent a dummy variable for the treatment group, $M$ a dummy variable for the treatment municipalities, and $T$ a dummy variable for the treatment period $(T) .{ }^{15}$ The main parameter of interest in equation (2) is $\delta$, which represents the treatment effect based on the triple-difference approach.

The first parameter, $\gamma_{1}$, captures the differences between the treatment and the control group (identification comes from the control period and the control municipalities). The second parameter, $\gamma_{2}$, captures the difference between the treatment period and the control period (identification comes from the control group and the control municipalities). Parameter $\gamma_{3}$ captures the possible differences between the treatment groups in the municipalities that did and did not implement the instruments (identification comes from the control period). The period effect may be different for the treatment and control municipalities, which is captured by the fourth parameter $\left(\gamma_{4}\right)$. Parameter $\gamma_{5}$ represents the interaction between the treatment group and the treatment period.

The determinants of earnings $y_{i t}$ that single mother $i$ receives in time period $t$ in addition to her welfare benefit is established using a linear regression model of the form

$$
y_{i t}=X_{i t} \rho+D_{i t} \kappa+\varepsilon_{i t}
$$

\footnotetext{
${ }^{14}$ Unfortunately, we do not have information about reemployment bonuses in control municipalities. However, for all treatment municipalities we know whether and in which years they provided reemployment bonuses to the control group and the treatment group. To correct for this we include interactions of year and the provision of a reemployment bonus (yes $=1, \mathrm{no}=0$ ). In addition, we allow these effects to be different for the treatment and the control group, and later on within the treatment group for single mothers with the youngest child younger or older than 5 .

${ }^{15}$ We do not include $M$ as a separate variable, because all treatment municipality dummies are already included in $X$. Also note that $G$ is a time-varying variable as a single mother may switch between groups due to the introduction of the new policy or because of the fact that her youngest child turns 12 years of age. Results hardly change when we exclude the 177 untreated single mothers who are untreated because their children passed the age of 12 during the treatment period.
} 
where $X_{i t}$ and $D_{i t}$ are specified before. In the same way, welfare benefits per recipient, paid by the municipalities, and income are modeled using linear regression models. By computing clustered standard errors, we take into account that for some individuals we have multiple observations. ${ }^{16}$

\subsection{Parameter estimates}

We present the results of our empirical analysis in three steps. In this section we present the overall effectiveness of the policy instruments. In section 5.3 we investigate the effect of the earnings disregard and job creation separately. In section 5.4 we investigate whether the treatment effects differ within the treatment group, making a distinction between single mothers with very young children aged 0 to 4 and single mothers with older children aged 5 to 11 .

Table 4 shows the estimated total treatment effects. Panel I of table 4 shows the parameters estimates of the treatment. The full parameter estimates are presented in tables B.1 and B.2. ${ }^{17}$ To improve the interpretation of the treatment effects, panel II of table 4 presents average adjusted predictions and average marginal effects. The average adjusted predictions show the average probability of part-time employment and outflow within two years after the start of a welfare spell, in case all treated single mothers who entered welfare during the experiment would (or would not) have received the treatment. The difference gives us the average marginal effect of the treatment. As shown in panel Ia and IIa of table 4, the treatment increased the inflow rate to a part-time job for immigrant single mothers significantly. The inflow to part-time work within two years after the start of a welfare spell increased by $18.7 \%$-points, from $4.6 \%$ to $23.4 \%$. For native single mothers there is no significant treatment effect. From panel Ib and IIb of table 4 it appears that outflow from welfare is not significantly affected by the treatment. Panel Ic shows that for both immigrant single mothers and native single mothers the policies increased earnings; $€ 95$ per month for immigrant single mothers and $€ 62$ per month for native single mothers. This means that immigrant single mothers increased their participation on average with about 3 hours per week and native single mothers with about 2 hours per week. ${ }^{18}$ Welfare benefits go down for both groups albeit the effect is only significant - at a $10 \%$ level for immigrant single mothers. It is reassuring that the reduction in welfare benefits because of the experiment is lower than the earnings growth, since only part of the earnings ( $€ 4$ per hour)

\footnotetext{
${ }^{16}$ In the robustness checks we also cluster standard errors at the municipality level.

${ }^{17}$ With regard to the control variables appendix table B.1 shows that the inflow into part-time employment increases with the age of the children and decreases with the number of children in the household. Lone single mothers who receive alimony start working part-time sooner than single mothers without any alimony and immigrants, especially first generation immigrants, are less likely to start a part-time job in addition to their welfare benefits. The longer people are in welfare without a part-time job, the less likely they are to start a part-time job (state dependence). Related to this, we find that the unobserved heterogeneity term is significant (the variance of the unobserved heterogeneity term, $\alpha$, is significantly positive).

${ }^{18} 95 /(€ 8 \times 4$ weeks $) \approx 3$ and $62 /(€ 8 \times 4$ weeks $) \approx 2$.
} 
are exempted from welfare benefits.

Finally, a potential effect of the experiment is poverty reduction among single mothers on welfare. This can also indirectly improve other aspects of life, such as health and self-esteem of the single mother. Panel Ie shows that single mother welfare recipients experience a net increase in their income, although this is only significant for immigrant single mothers. When we compare the results in table 4 with the triple difference estimates in table 3 , we find that taking into account unobserved heterogeneity and observed differences between single mothers does not change the estimated treatment effects on the time to employment and outflow from welfare ${ }^{19}$, but increases the estimated treatment effects on earnings, welfare benefits and income.

\subsection{Sensitivity analysis - heterogeneous treatment effects}

As indicated before, municipalities applied different types of policies to persuade single mothers to find (part-time) jobs. All treatment municipalities allowed single mothers in the treatment group an earnings disregard. In addition to that, some municipalities stimulated direct job creation in the public and private sector. By way of sensitivity analysis table 5 shows to what extent different policy measures had different treatment effects. ${ }^{20}$ Panel Ia shows that for immigrant single mothers the earnings disregard had a significant positive effect on the inflow to a part-time job but job creation did not have a significant additional positive effect. The average marginal effect in panel IIa shows that the earnings disregard increased part-time employment within two years on average with $13.9 \%$-points, from $4.2 \%$ to $18.1 \%$. For native single mothers none of the two instruments was significantly effective. For the outflow from welfare we find no significant effect of both instruments.

As shown in panel Ic of table 5, the earnings disregard increased earnings of immigrant single mothers significantly with $€ 83$ per month, which implies an increased participation of about

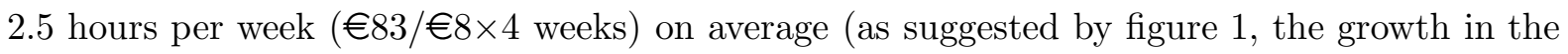
number of hours worked per week is small). For native single mothers the effect of the earnings disregard on earnings was also positive (€49, about 1.5 hours per week), but not significant. For both types of mothers, job creation had an additional significant positive effects on earnings. Since the time to employment was not increased by direct job creation (panel a), single mothers probably started jobs for more hours per week than they would have done without direct job

\footnotetext{
${ }^{19}$ The average adjusted predictions with treatment in table 4 can to some extent be compared with the employment and outflow rates of treated parents in table 3 . However, the selection and underlying methods are different. The rates in table 3 are collected from figures 3 and 4 and are based on all individuals that participated in the experiment (also those who started their welfare spell before the experiment). Panel II of table 4, on the other hand, shows the employment and outflow rates only for individuals that entered welfare during the experiment. They received the treatment as from the start of their welfare spell and the employment and outflow rates are calculated using the model results.

${ }^{20}$ For this sensitivity analysis we included a treatment variables function (like equation 2) for the 6 municipalities that implemented direct job creation, the period in which job creation took place, and the treatment group.
} 
creation.

One of the aims of the experiment was to decrease welfare expenditures. When the experimental instruments increase labor force participation and/or the number of hours worked, and only part of labor income is exempted from the welfare benefit, this has a positive effect on the welfare benefits paid by the municipality. On the other hand, single mothers that already worked part-time before the experiment was implemented now receive an earnings disregard of $€ 4$ per hour, whereas they received nothing before the experiment. This has a negative effect on the amount of welfare benefits per welfare recipient paid by the municipality. Panel Id of table 5 shows that the positive effect dominates, but that the effect of the earnings disregard is not significant. Job creation, additional to the earnings disregard, significantly reduced welfare benefits for immigrant and native single mothers by $€ 55$ and $€ 57$, respectively. The sum of welfare benefits and earnings is only positive for immigrant single mothers through the effect of the earnings disregard.

\subsection{Sensitivity analysis - heterogeneous treatment groups}

Table 6 presents the parameter estimates of the heterogeneous treatment effect on the various outcome measures if we distinguish two treatment groups, single mothers with the youngest child aged between 0 and 4 years and single mothers with the youngest child aged between 5 and 11 years. ${ }^{21}$ Panel Ia and IIa of table 6 show the estimated treatment effects for the inflow to part-time work. Comparing the parameter estimates with those in panel Ia and IIa of table 5 it is clear that making a distinction between two treatment groups does not add much to the insight in the policy effects. The parameter estimates for the two treatment groups are not significantly different. Estimation results for the outflow from welfare are reported in panel Ib and IIb of table 6 and are also not significantly different for the two treatment groups.

Panel Ic of table 6 shows that direct job creation was significantly effective for the earnings of immigrants with children of age 5-11 (an income growth of $€ 79$ per month) and natives with the youngest child aged between 0 and 4 years (€94 per month), but not for immigrants with the youngest child aged between 0 and 4 years and natives with the youngest child aged between 5 and 11 years. Regarding job creation we measure the intention to treat. Immigrant single mothers with the youngest child between the age of 0 and 4 are the most difficult category within the treatment group and are less often approached by municipalities to participate in the labor pool. This may explain the insignificant effect of job creation for this group. On the other hand, natives with the youngest child aged between 5 and 11 years (the most 'easy' category within the treatment group) are approached frequently but probably need less help in finding a job, such that direct job creation is not significantly effective for them. As mentioned before, since

\footnotetext{
${ }^{21}$ For this sensitivity analysis we used interactions with a dummy variable indicating whether the youngest child in the household was aged between 5 and 11 years.
} 
the time to employment was not reduced by direct job creation (panel a), immigrant mothers with the youngest child aged between 5 and 11 years and native mothers with the youngest child aged between 0 and 4 years probably start jobs of more hours per week than they would do without direct job creation.

The estimated treatment effects for welfare benefits, reported in panel d of table 6 are significantly different for immigrant single mothers with children between the age of 0-4 and 5-11. The earnings disregard reduced welfare benefits significantly for immigrant mothers with the youngest child between the age of 0 and 4 years, but not for immigrant single mothers with the youngest child aged between 5 and 11 years. This can be explained by the fact that in the last group (with older children) relatively more single mothers would have worked anyway (also without the earnings disregard). In the experiment these mothers received an earnings disregard of $€ 4$ per hour, whereas they received nothing outside the experiment. This reduced the financial advantage for the municipalities for this group. Job creation as an additional instrument, on the other hand, is more effective for immigrant single mothers with children between 5 and 11 years and for native single mothers with children between 0 and 4 years (just like we explained for panel c above). Finally, panel e of table 6 shows the estimated treatment effects on income, which are not significantly different for single mother with young (0-4 years) and old (5-11 years) children.

\subsection{Robustness checks}

To check the validity of the results table 7 presents the results of two placebo tests. Part I of the table presents estimated treatment effects when we assume that the treatment already took place in 2007-2008 instead of 2009-2010 (fake treatment period). Almost none of the variables of interest are significant (as it should be). Only for immigrants we find a weakly significant treatment effect with regard to welfare benefits. In part II of table 7 fourteen fake treatment municipalities are randomly chosen from all municipalities in the Netherlands. Also here we find almost no significant treatment effects, except for a weak significant effect for the outflow of immigrants.

In additional robustness checks not reported we considered data selections with more narrow ranges around the age limit of 12 years for the youngest child in the household, such as the range from 7 to 16 years. The results hardly change. Only, a smaller age range leads to a significant reduction of welfare benefits for natives (on average -88 euro instead of -35 euro found in table 4). Furthermore, we considered selections of spells based on the cause of the welfare spell (end of job, end of marriage and end of education). The results are about the same, but less significant, probably because of the smaller sample sizes. Finally, for the last robustness check we cluster standard errors at the municipality level. The same coefficients 
remain significant in table $4 .{ }^{22}$

\section{Conclusions}

Single mothers with young children are often long-term recipients of welfare benefits. Financial incentives to leave welfare for work are not very strong. Usually, benefits are reduced one-for-one when they accept a job and start earning money. To explore the possibilities of bringing single mothers with young children from welfare to work in 2009 and 2010 the Dutch government funded a policy experiment in which an earnings disregard was introduced that was sometimes combined with job creation. The experiment was performed at the level of municipalities in the Netherlands. Our paper presents an analysis about the effectiveness of both policies. We evaluate the effectiveness of the policy experiment as if it was a natural experiment by comparing the calendar time periods before and during the experiment, the municipalities with and without the experimental policy instruments and by comparing single mothers with young children (who are treated) and single mothers with older children (who are not treated). In our analysis we make a distinction between native single mothers and immigrant single mothers as the latter group has a particularly weak labor market position. In addition, we differentiate the treatment effect for single mothers with the youngest child between the age of 0 and 4 and single mothers with the youngest child between the age of 5 and 11, as both have different needs for care.

Our main findings are that the earnings disregard stimulated work and earnings of immigrant single mothers. In addition, job creation reduced welfare benefits and increased earnings for immigrant single mothers with the youngest child between the age of 5 and 11 and for native single mothers with the youngest child between the age of 0 and 4 . Regarding job creation, we measure an intention to treat. This means that we do not have to worry about a non-random selection of single mothers into the treatment and that we take into account the success or failure that municipalities experience in finding jobs for single mothers. Nevertheless, we may underestimate the potential effectiveness of job creation. Welfare expenditures are reduced by the experiment. The earnings disregard significantly reduced welfare benefits for immigrant single mothers with the youngest child between 0 and 4 years. That is because labor force participation increased for this group and almost no disregards had to be paid to mothers that would also have worked without the financial incentive. Income increased significantly for immigrant single mothers with the youngest child between 5 and 11 years. This also implies favorable effects on the children in these households. The earnings disregard and job creation do not provide incentives to flow out of welfare in the short run, but they also did not reduce

\footnotetext{
${ }^{22}$ For natives the treatment effect on earnings becomes significant at the $1 \%$-level instead of the 5-\% level. For immigrants the significance of the treatment effect on welfare benefits increases from the $10 \%$ to the $1 \%$-level. Finally, the significance of the treatment effect on income decreases for immigrants from the $5 \%$ to the $10 \%-l e v e l$.
} 
outflow from welfare (the attractiveness of the instruments may keep single mothers in welfare). The overall effect of income disregards is a combination of the effects of financial incentives and the monitoring by case workers as part of the new policy (some treated mothers got an individual appointment with a case worker to inform them about the experiment and review their situation). A surprising finding is that income disregards are mostly effective for immigrant single mothers, who are at the low end of the earnings distribution. A possible explanation for this finding is that usually immigrant single mothers were no target group in activation policies. Maybe the effect for native single mothers is lower than for immigrant single mothers because they were monitored already more strictly and were more engaged in activation policies. Furthermore, the lack of effects for native single mothers could have to do with the situation in the labor market. During the period of the experiment there was little or no job growth in the Netherlands which could have influenced the results. On the other hand, the labor market position of immigrant single mothers on welfare was so weak that it could only improve by providing the right incentives. Maybe, it is not the immigrant status itself that causes a higher receptiveness to the instruments. For example, if immigrant single mothers have a lower education level on average, and the effect of the policy instruments are higher for lower-educated single mothers, this also explains the difference. Furthermore, maybe low wage individuals feel more attracted by the earnings disregard as they benefit the most (relatively) from the earnings disregard (they may keep a larger share of their earnings). If this is the case this may also explain the difference between immigrant and native single mothers, when wage rates are on average lower for immigrant single mothers than for native single mothers. Finally, native single mothers may receive more informal financial support from their parents than immigrant single mothers whose parents live outside the Netherlands. That would make native single mothers less sensitive to financial incentives than immigrant single mothers.

The purpose of the policy experiment was to induce single mothers on welfare to enter the labor market if only through a part-time job. This might make it easier for them to find a full-time job later on in life. The goal of the experiment, to increase part-time work among single mothers on welfare and decrease welfare expenditures, succeeded. From a policy point of view, the earnings disregard is an effective instrument to increase labor force participation and earnings of immigrant single mothers with children younger than 12 years. Nevertheless, as predicted by comparing the budget constraint with and without the experiment, the extra number of hours worked because of the policy experiment is small. If one aims to reduce welfare benefits by using an earnings disregard, it would be wise to lower the age limit of 12 years, to reduce the number of disregards given to single mothers that would have worked anyway. Job creation, in addition to the earnings disregard, also induces lower welfare benefits for single mothers with older children. Of course the efficiency of job creation depends on the 
costs that municipalities have to make to find jobs for the single mothers. Furthermore, after the implementation of an earnings disregard additional screening may be necessary, to prevent single mothers to enter welfare because of the attractiveness of the earnings disregard. 


\section{References}

Anderson, P. (1992). Time-varying effects of recall expectation, a reemployment bonus, and job counseling on unemployment durations. Journal of Labor Economics 10, 99-115.

Bettendorf, L., K. Folmer, and E. Jongen (2013). The dog that did not bark: The EITC for single mothers in the Netherlands. CPB Discussion Paper 229, forthcoming in Journal of Public Economics.

Blundell, R., M. Brewer, P. Haan, and A. Shephard (2009). Optimal income taxation of lone mothers: an empirical comparison of the UK and Germany. Economic Journal 119, F101-F121.

Blundell, R. and H. Hoynes (2004). Seeking a Premier Economy: The Economic Effects of British Economic Reforms, 1980-2000, Chapter Has "in-work" benefit reform helped the labor market?, pp. 411-460. Chicago, U.S.: University of Chicago Press.

Blundell, R. and T. Macurdy (1999). Labor supply: A review of alternative approaches. In O. Ashenfelter and D. Card (Eds.), Handbook of Labor Economics, Volume 3, Chapter 27, pp. 1559-1695. Elsevier.

Boeri, T. (1997). Labor market reforms in transition economies. Oxford Review of Economic Policy 13(2), $126-140$.

Brewer, M. (2001). Comparing in-work benefits and the reward to work for families with children in the US and the UK. Fiscal Studies 22(1), 41-77.

Brewer, M., A. Duncan, and A. Shephard (2007). Did working families' tax credit work? the impact of in-work support on labour supply in Great Britain. Labour Economics 13(3), 699-720.

Campolieti, M. (2004). Disability insurance benefits and labor supply: Some additional evidence. Journal of Labor Economics 22, 863-889.

Card, D. and D. Hyslop (2005). Estimating the effects of a time-limited earnings subsidy for welfareleavers. Econometrica 73, 1723-1770.

Decker, P. and C. O'Leary (1995). Evaluating pooled evidence from the reemployment bonus experiments. Journal of Human Resources 30, 534-550.

Eissa, N. and J. Liebman (1996). Labor supply response to the earned income tax credit. Quarterly Journal of Economics 111(2), 605-637.

Ellwood, D. (2000). The impact of the earned income tax credit and social policy reforms on work, marriage, and living arrangements. National Tax Journal 53(4), 1063-1105.

Fernandez, R. (2007). Women, work and culture. Journal of European Economic Association 5(2-3), 305-332.

Gruber, J. (1994). The incidence of mandated maternity benefits. American Economic Review 84, $622-641$.

Hamermesh, D. and S. Trejo (2000). The demand for hours of labor: Direct evidence from California. Review of Economics and Statistics 82, 38-47.

Heckman, J. J., R. J. Lalonde, and J. A. Smith (1999, October). The economics and econometrics of active labor market programs. In O. Ashenfelter and D. Card (Eds.), Handbook of Labor Economics, Volume 3 of Handbook of Labor Economics, Chapter 31, pp. 1865-2097. Elsevier.

Hotz, V., C. Mullin, and J. Scholz (2001). The earned income tax credit and the labor market participation of families on welfare. Working paper, university of Wisconsin.

Immervoll, H. and M. Pearson (2009). A good time for making work pay? Taking stock of in-work benefits and related measures across the OECD. OECD Social, Employment and Migration Working Papers, no. 81 . 
Kluve, J. (2010). The effectiveness of European active labor market programs. Labour Economics 17, 904-918.

Kok, S., N. Bosch, A. Deelen, and R. Euwals (2011). Migrant women on the labour market; on the role of home- and host-country participation. CPB discussion paper nr. 180.

Martin, J. and D. Grubb (2001). What works and for whom: a review of OECD countries' experience with active labor market policies. Swedish Economic Policy Review 8(2), 9-56.

Matsudaira, J. D. and R. M. Blank (2013). The impact of earnings disregards on the behavior of low income families. Journal of policy analysis and management, 1-29.

McKernan, S.-M., R. I. Lerman, N. Pindus, and J. Valente (2000). The relationship between metropolitan and nonmetropolitan locations, changing welfare policies, and the employment of single mothers. Joint Center for Poverty Research, Working Paper No. 192. Chicago, IL: Joint Center for Poverty Research, Northwestern University/University of Chicago.

Meghir, C. and D. Philips (2010). Labour supply and taxes. In J. Mirrlees, S. Adam, T. Besley, R. Blundell, S. Bond, R. Chote, M. Gammie, P. Johnson, G. Myles, and J. Poterba (Eds.), Dimensions of tax design, Chapter 3, pp. 202-274. Oxford University Press.

Meyer, B. (1995). Lessons from the U.S. unemployment insurance experiments. Journal of Economic Literature 33, 91-131.

Meyer, B. (2002). Labor supply at the extensive and intensive margins: The EITC, welfare, and hours worked. American Economic Review 92(2), 373-379.

Meyer, B. and D. Rosenbaum (2001). Welfare, the earned income tax credit, and the labor supply of single mothers. Quarterly Journal of Economics 116(3), 1063-1114.

Michalopoulos, C., P. Robins, and D. Card (2005). When financial work incentives pay for themselves: evidence from a randomized social experiment for welfare recipients. Journal of Public Economics 89, $5-29$.

Noonan, M., S. Smith, and M. Corcoran (2007). Examining the impact of welfare reform, labor market conditions, and the earned income tax credit on the employment of black and white single mothers. Social Science Research 36(1), 95-130.

O'Leary, C., P. Decker, and S. Wandner (2005). Cost-effectiveness of targeted reemployment bonuses. Journal of Human Resources 40(1), 270-279.

O’Neill, J. E. and M. A. Hill (2001). Gaining ground? measuring the impact of welfare reform on welfare and work. Civic Report No. 17. New York, NY: Manhattan Institute, Center for Civic Innovation.

Statistics Netherlands (2011). Sociaaleconomische trends, 2e kwartaal 2011. Publication Statistics Netherlands.

Van der Klaauw, B. and J. C. van Ours (2013). Carrot and stick: How reemployment bonuses and benefit sanctions affect exit rates from welfare. Journal of Applied Econometrics 28, 275-296.

Woodbury, S. and R. Spiegelman (1987). Bonuses to workers and employers to reduce unemployment: Randomized trials in Illinois. American Economic Review 77, 513-530. 
Table 1: Number of welfare spells per single mother

\begin{tabular}{lrrrrrrrrrr}
\hline & \multicolumn{3}{c}{ Treatment municipality } & \multicolumn{3}{c}{ Control municipality } & \multicolumn{2}{c}{ Total } \\
& \multicolumn{2}{c}{ Treatment group } & \multicolumn{2}{c}{ Control group } & \multicolumn{2}{c}{ Treatment group } & Control group & & \\
\# Spells & Freq. & $\%$ & Freq. & $\%$ & Freq. & $\%$ & Freq. & $\%$ & Freq. & $\%$ \\
\hline 1 & 5584 & 86.3 & 854 & 88.4 & 41288 & 85.6 & 6650 & 90.3 & 54376 & 86.2 \\
2 & 767 & 11.9 & 96 & 9.9 & 6206 & 12.9 & 650 & 8.8 & 7719 & 12.2 \\
3 & 107 & 1.7 & 13 & 1.4 & 680 & 1.4 & 61 & 0.8 & 861 & 1.4 \\
4 & 12 & 0.2 & 3 & 0.3 & 72 & 0.2 & 6 & 0.1 & 93 & 0.1 \\
5 & 3 & 0.1 & 0 & 0 & 5 & 0.0 & 1 & 0.0 & 9 & 0.0 \\
\hline Total mothers & 6473 & 100 & 966 & 100 & 48251 & 100 & 7368 & 100 & 63058 & 100 \\
Total spells & 7502 & & 1097 & & 56053 & & 8162 & & 72814 & \\
\hline
\end{tabular}

Note: Treatment municipality = municipality that implemented the instruments; control municipality= all other Dutch municipalities; treatment group = single mothers with children younger than 12 years; control group $=$ single mothers with all children 12 years or older. Single mothers are classified into the category of their first welfare spell. 
Table 2: Characteristics of the sample

\begin{tabular}{|c|c|c|c|c|c|c|c|c|}
\hline & \multicolumn{4}{|c|}{ Treatment municipalities } & \multicolumn{4}{|c|}{ Control municipalities } \\
\hline & \multicolumn{2}{|c|}{ Control period } & \multicolumn{2}{|c|}{ Treatment period } & \multicolumn{2}{|c|}{ Control period } & \multicolumn{2}{|c|}{ Treatment period } \\
\hline & $\begin{array}{l}\text { Treatment } \\
\text { group }\end{array}$ & $\begin{array}{l}\text { Control } \\
\text { group }\end{array}$ & $\begin{array}{l}\text { Treatment } \\
\text { group }\end{array}$ & $\begin{array}{l}\text { Control } \\
\text { group }\end{array}$ & $\begin{array}{l}\text { Treatment } \\
\text { group }\end{array}$ & $\begin{array}{l}\text { Control } \\
\text { group }\end{array}$ & $\begin{array}{l}\text { Treatment } \\
\text { group }\end{array}$ & $\begin{array}{c}\text { Control } \\
\text { group }\end{array}$ \\
\hline Average age single mother & 32.5 & 38.3 & 33.4 & 41.7 & 33.2 & 39.3 & 34.2 & 42.9 \\
\hline Average age youngest child & 4.0 & 13.8 & 4.5 & 13.9 & 4.2 & 13.8 & 4.7 & 13.9 \\
\hline Average number of children & 1.9 & 1.7 & 1.9 & 1.6 & 1.9 & 1.8 & 2.0 & 1.7 \\
\hline$\%$ Unmarried & 50.9 & 40.2 & 53.9 & 36.6 & 43.7 & 33.3 & 46.7 & 26.5 \\
\hline$\%$ Divorced & 26.1 & 41.1 & 30.3 & 47.8 & 30.1 & 45.0 & 34.6 & 57.2 \\
\hline$\%$ Married & 22.5 & 17.4 & 15.2 & 15.0 & 25.4 & 20.1 & 18.0 & 15.2 \\
\hline$\%$ Widowed & 0.4 & 1.2 & 0.4 & 0.6 & 0.5 & 1.3 & 0.5 & 1.1 \\
\hline$\%$ Cohabiting & 0.1 & 0.0 & 0.2 & 0.1 & 0.3 & 0.2 & 0.2 & 0.1 \\
\hline \% First generation non-western immigrants & 34.9 & 25.7 & 36.7 & 33.3 & 31.0 & 24.1 & 33.3 & 30.3 \\
\hline$\%$ Second generation non-western immigrants & 6.9 & 4.4 & 8.8 & 3.4 & 5.0 & 3.3 & 6.4 & 2.4 \\
\hline \% Immigrants from Western countries & 10.4 & 13.7 & 10.2 & 13.6 & 10.5 & 12.3 & 10.7 & 12.4 \\
\hline$\%$ Receiving labor income & 18.9 & 22.7 & 20.2 & 22.1 & 20.9 & 26.6 & 22.3 & 26.2 \\
\hline$\%$ Receiving alimony & 10.7 & 12.5 & 11.8 & 15.7 & 14.8 & 15.6 & 16.0 & 18.6 \\
\hline$\%$ Home owner & 3.7 & 3.9 & 3.7 & 3.7 & 3.6 & 3.4 & 2.9 & 3.3 \\
\hline \# Spells & 4793 & 632 & 2662 & 515 & 36384 & 4755 & 19131 & 3942 \\
\hline
\end{tabular}

Note: Treatment municipality $=$ municipality that implemented the instruments; control municipality = all other municipalities; treatment period $=$ 2009-2010; control period $=2005$-2008; treatment group $=$ single mothers with children younger than 12 years; control group $=$ single mothers with all children 12 years or older. 
Table 3: Treatment effects - exploratory analysis

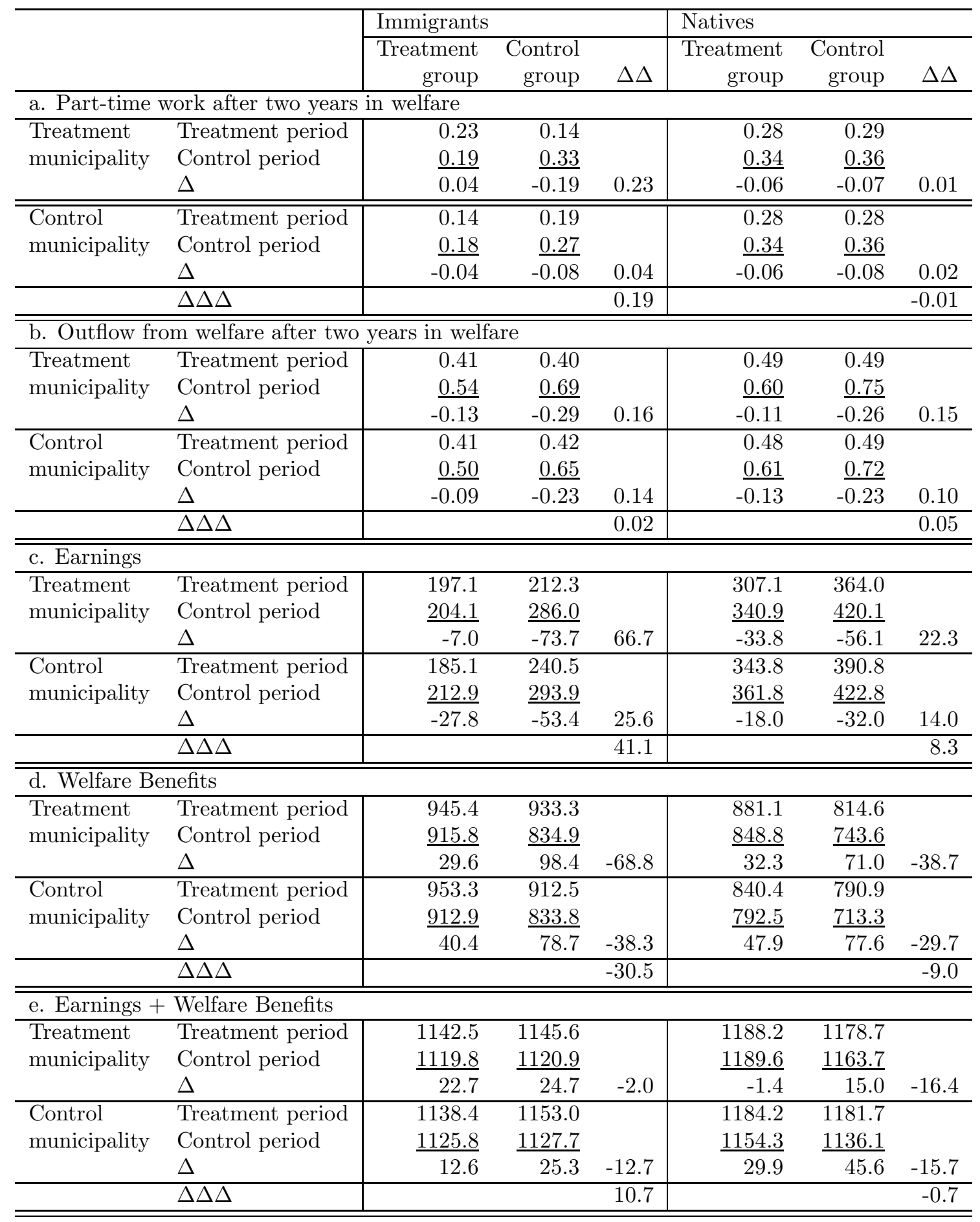

Note: This table provides an indication of the treatment effect using a triple difference approach; $\Delta=$ first difference; $\Delta \Delta=$ Difference in differences; $\Delta \Delta \Delta=$ Triple difference. Treatment municipality $=$ municipality that implemented the new policy; control municipality = all other Dutch municipalities; treatment group $=$ single mothers with children younger than 12 years; control group $=$ single mothers with all children 12 years or older. Natives are defined as native Dutch or Western immigrants. Earnings and welfare benefits in $€$ per month. 
Table 4: Treatment effects - empirical models

\begin{tabular}{lcc|cc}
\hline & \multicolumn{3}{c}{ Immigrants } & \multicolumn{2}{c}{ Natives } \\
& Coeff. & S.E. & Coeff. & S.E. \\
\hline I. Parameter estimates total treatment effect & \multicolumn{4}{l}{} \\
\hline a. Time to (part-time) employment & $1.778^{* * *}$ & 0.575 & -0.130 & 0.310 \\
b. Outflow from welfare & 0.237 & 0.290 & -0.120 & 0.158 \\
c. Earnings & $0.095^{* * *}$ & 0.033 & $0.062^{* *}$ & 0.031 \\
d. Welfare benefits & $-0.051^{*}$ & 0.030 & -0.035 & 0.029 \\
e. Income (earnings + welfare benefits) & $0.044^{* *}$ & 0.023 & 0.027 & 0.024 \\
\hline \multicolumn{4}{l}{} \\
II. Average adjusted predictions and average marginal effects & & \multicolumn{2}{l}{} \\
\hline a. Part-time employment within two years in welfare & 0.046 & 0.029 & $0.341^{* * *}$ & 0.084 \\
1) No treatment & $0.234^{* * *}$ & 0.018 & $0.307^{* * *}$ & 0.018 \\
2) Treatment & $0.187^{* * *}$ & 0.039 & -0.034 & 0.089 \\
2-1) Treatment effect & \multicolumn{3}{l}{} \\
\hline b. Outflow from welfare within two years in welfare & $0.220^{* * *}$ & 0.062 & $0.501^{* * *}$ & 0.049 \\
1) No treatment & $0.269^{* * *}$ & 0.015 & $0.461^{* * *}$ & 0.014 \\
2) Treatment & 0.049 & 0.065 & -0.040 & 0.050 \\
2-1) Treatment effect
\end{tabular}

Note: Earnings, welfare benefits and income in $€ 1000$ per month. Natives are defined as native Dutch or Western immigrants. Panel I contains parameter estimates of the treatment effects. Panel II contains average adjusted predictions and average marginal effects for the inflow to part-time work and the outflow from welfare. The average adjusted predictions show the average probability of part-time employment and outflow within two years after the start of a welfare spell, in case all treated single mothers who entered welfare during the experiment would (or would not) have received the treatment. The difference gives us the average marginal effect of the treatment. In the predictions the unobserved individual specific effect $\left(u_{i}\right)$ is assumed to be one. For the bootstrapped standard errors we used 250 replications. 
Table 5: Heterogeneous treatment effects

\begin{tabular}{|c|c|c|c|c|}
\hline & \multicolumn{2}{|c|}{ Immigrants } & \multicolumn{2}{|c|}{ Natives } \\
\hline & Coeff. & S.E. & Coeff. & S.E. \\
\hline \multicolumn{5}{|l|}{ I. Parameter estimates treatment effects } \\
\hline \multicolumn{5}{|l|}{ a. Time to (part-time) employment } \\
\hline Earnings disregard & $1.592^{* *}$ & 0.629 & -0.247 & 0.319 \\
\hline Job creation & 0.486 & 0.617 & 0.562 & 0.383 \\
\hline \multicolumn{5}{|l|}{ b. Outflow from welfare } \\
\hline Earnings disregard & 0.369 & 0.314 & -0.143 & 0.162 \\
\hline Job creation & -0.544 & 0.387 & 0.086 & 0.211 \\
\hline \multicolumn{5}{|l|}{ c. Earnings } \\
\hline Earnings disregard & $0.083^{* *}$ & 0.032 & 0.049 & 0.031 \\
\hline Job creation & $0.065^{*}$ & 0.036 & $0.078^{* *}$ & 0.038 \\
\hline \multicolumn{5}{|l|}{ d. Welfare benefits } \\
\hline Earnings disregard & -0.038 & 0.030 & -0.025 & 0.029 \\
\hline Job creation & $-0.055^{*}$ & 0.031 & $-0.057^{*}$ & 0.033 \\
\hline \multicolumn{5}{|l|}{ e. Income (earnings + welfare benefits) } \\
\hline Earnings disregard & $0.045^{*}$ & 0.024 & 0.025 & 0.025 \\
\hline Job creation & 0.010 & 0.024 & 0.020 & 0.026 \\
\hline \multicolumn{5}{|c|}{ II. Average adjusted predictions and average marginal effects } \\
\hline \multicolumn{5}{|c|}{ a. Part-time employment within two years } \\
\hline 1) No treatment & 0.042 & 0.028 & $0.305^{* * *}$ & 0.082 \\
\hline 2) Earnings disregard & $0.181^{* * *}$ & 0.069 & $0.249 * * *$ & 0.039 \\
\hline 3) Earnings disregard + job creation & $0.270 * * *$ & 0.073 & $0.390 * * *$ & 0.064 \\
\hline 2-1) Effect earnings disregard & $0.139^{* *}$ & 0.064 & -0.056 & 0.084 \\
\hline 3-2) Effect job creation & 0.089 & 0.134 & 0.141 & 0.096 \\
\hline 3-1) Total treatment effect & $0.228^{* *}$ & 0.091 & 0.085 & 0.119 \\
\hline \multicolumn{5}{|l|}{ b. Outflow from welfare within two years } \\
\hline 1) No treatment & $0.252^{* * *}$ & 0.074 & $0.497^{* * *}$ & 0.050 \\
\hline 2) Earnings disregard & $0.341^{* * *}$ & 0.060 & $0.450 * * *$ & 0.034 \\
\hline 3) Earnings disregard + job creation & $0.217^{* * *}$ & 0.038 & $0.478^{* * *}$ & 0.043 \\
\hline 2-1) Effect earnings disregard & 0.089 & 0.080 & -0.047 & 0.052 \\
\hline 3-2) Effect job creation & -0.124 & 0.092 & 0.028 & 0.072 \\
\hline 3-1) Total treatment effect & -0.035 & 0.093 & -0.019 & 0.074 \\
\hline
\end{tabular}

Note: Earnings, welfare benefits and income in $€ 1000$ per month. Natives are defined as native Dutch or Western immigrants. Panel I shows the estimated treatment effect of the earnings disregard and the estimated treatment effect of job creation on top of the earnings disregard. Panel II contains average adjusted predictions and average marginal effects for the inflow to part-time work and the outflow from welfare. The average adjusted predictions show the average probability of part-time employment and outflow within two years after the start of a welfare spell, in case all treated single mothers who entered welfare during the experiment would (or would not) have received the treatment. The difference gives us the average marginal effect of the treatment. In the predictions the unobserved individual specific effect $\left(u_{i}\right)$ is assumed to be one. For the bootstrapped standard errors we used 250 replications. 
Table 6: Treatment effects: differentiated by age of the youngest child

\begin{tabular}{|c|c|c|c|c|c|c|c|c|}
\hline \multirow{3}{*}{ Age youngest child } & \multicolumn{4}{|c|}{ Immigrants } & \multicolumn{4}{|c|}{ Natives } \\
\hline & \multicolumn{2}{|c|}{$0-4$} & \multicolumn{2}{|c|}{$5-11$} & \multicolumn{2}{|c|}{$0-4$} & \multicolumn{2}{|c|}{$5-11$} \\
\hline & Coeff. & S.E. & Coeff. & S.E. & Coeff. & S.E. & Coeff. & S.E. \\
\hline \multicolumn{9}{|c|}{ I. Parameter estimates treatment effects } \\
\hline \multicolumn{9}{|c|}{ a. Time to (part-time) employment } \\
\hline Earnings disregard & $1.444^{* *}$ & 0.649 & $1.801^{* * *}$ & 0.654 & -0.262 & 0.349 & -0.228 & 0.346 \\
\hline Job creation & 0.655 & 0.640 & 0.310 & 0.648 & 0.544 & 0.411 & 0.595 & 0.415 \\
\hline \multicolumn{9}{|c|}{ b. Outflow from welfare } \\
\hline Earnings disregard & 0.316 & 0.327 & 0.442 & 0.341 & -0.157 & 0.178 & -0.122 & 0.178 \\
\hline Job creation & -0.529 & 0.407 & -0.579 & 0.428 & -0.056 & 0.230 & 0.240 & 0.233 \\
\hline \multicolumn{9}{|l|}{ c. Earnings } \\
\hline Earnings disregard & $0.096^{* * *}$ & 0.033 & $0.076^{* *}$ & 0.034 & 0.043 & 0.033 & $0.061^{*}$ & 0.034 \\
\hline Job creation & 0.049 & 0.037 & $0.079 * *$ & 0.039 & $0.094^{* *}$ & 0.039 & 0.061 & 0.041 \\
\hline \multicolumn{9}{|l|}{ d. Welfare benefits } \\
\hline Earnings disregard & $-0.055^{*}$ & 0.031 & -0.023 & 0.031 & -0.006 & 0.031 & -0.047 & 0.031 \\
\hline Job creation & -0.033 & 0.033 & $-0.076^{* *}$ & 0.033 & $-0.057^{*}$ & 0.035 & -0.057 & 0.036 \\
\hline \multicolumn{9}{|c|}{ e. Income (earnings + welfare benefits) } \\
\hline Earnings disregard & 0.041 & 0.026 & $0.053^{* *}$ & 0.025 & 0.036 & 0.027 & 0.014 & 0.027 \\
\hline Job creation & 0.016 & 0.025 & 0.003 & 0.026 & 0.037 & 0.028 & 0.004 & 0.028 \\
\hline \multicolumn{9}{|c|}{ II. Average adjusted predictions and average marginal effects } \\
\hline \multicolumn{9}{|c|}{ a. Part-time employment within two years } \\
\hline 1) No treatment & 0.039 & 0.027 & 0.044 & 0.031 & $0.289^{* * *}$ & 0.086 & $0.324^{* * *}$ & 0.091 \\
\hline 2) $\mathrm{ED}$ & $0.202^{* *}$ & 0.089 & $0.229 * * *$ & 0.088 & $0.239^{* * *}$ & 0.064 & $0.269^{* * *}$ & 0.049 \\
\hline 3) $\mathrm{ED}+\mathrm{JC}$ & $0.261^{* * *}$ & 0.099 & $0.293^{* * *}$ & 0.079 & $0.386^{* * *}$ & 0.105 & $0.428^{* * *}$ & 0.068 \\
\hline 2-1) Effect ED & $0.164^{* *}$ & 0.082 & $0.184^{* *}$ & 0.079 & -0.050 & 0.085 & -0.055 & 0.091 \\
\hline 3-2) Effect JC & 0.058 & 0.148 & 0.064 & 0.155 & 0.148 & 0.103 & 0.159 & 0.105 \\
\hline 3-1) Total effect & $0.222^{* *}$ & 0.108 & $0.248^{* *}$ & 0.097 & 0.097 & 0.126 & 0.104 & 0.130 \\
\hline \multicolumn{9}{|c|}{ b. Outflow from welfare within two years } \\
\hline 1) No treatment & $0.298^{* * *}$ & 0.085 & $0.196^{* * *}$ & 0.066 & $0.553^{* * *}$ & 0.057 & $0.440^{* * *}$ & 0.052 \\
\hline 2) $\mathrm{ED}$ & $0.419^{* * *}$ & 0.088 & $0.286^{* * *}$ & 0.063 & $0.511^{* * *}$ & 0.057 & $0.402^{* * *}$ & 0.034 \\
\hline 3) $\mathrm{ED}+\mathrm{JC}$ & $0.266^{* * *}$ & 0.083 & $0.173^{* * *}$ & 0.042 & $0.595^{* * *}$ & 0.067 & $0.478^{* * *}$ & 0.047 \\
\hline 2-1) Effect ED & 0.121 & 0.098 & 0.090 & 0.076 & -0.042 & 0.060 & -0.037 & 0.056 \\
\hline 3-2) Effect JC & -0.153 & 0.113 & -0.112 & 0.093 & 0.084 & 0.073 & 0.076 & 0.069 \\
\hline 3-1) Total effect & -0.032 & 0.115 & -0.022 & 0.087 & 0.042 & 0.080 & 0.038 & 0.077 \\
\hline
\end{tabular}

Note: Earnings, welfare benefits and income in $€ 1000$ per month. Natives are defined as native Dutch or Western immigrants. Panel I shows the estimated treatment effect of the earnings disregard and the estimated treatment effect of job creation on top of the earnings disregard. Panel II contains average adjusted predictions and average marginal effects for the inflow to part-time work and the outflow from welfare. The average adjusted predictions show the average probability of part-time employment and outflow within two years after the start of a welfare spell, in case all treated single mothers who entered welfare during the experiment would (or would not) have received the treatment. The difference gives us the average marginal effect of the treatment. In the predictions the unobserved individual specific effect $\left(u_{i}\right)$ is assumed to be one. For the bootstrapped standard errors we used 250 replications. ED = earnings disregard, JC = job creation. 
Table 7: Treatment effects for fake treatment period and fake treatment municipalities

\begin{tabular}{lcc|rr}
\hline & \multicolumn{2}{c}{ Immigrants } & \multicolumn{2}{c}{ Natives } \\
& Coeff. & \multicolumn{2}{c}{ S.E. } & \multicolumn{2}{c}{ Coeff. } & S.E. \\
\hline I. Parameter estimates total treatment effect with fake treatment period \\
\hline a. Time to (part-time) employment & -0.1202 & 0.5102 & 0.0215 & 0.3425 \\
b. Outflow from welfare & 0.1840 & 0.3144 & -0.1988 & 0.1706 \\
c. Earnings & 0.0235 & 0.0490 & -0.0422 & 0.0375 \\
d. Welfare benefits & $-0.0828^{*}$ & 0.0454 & -0.0765 & 0.0346 \\
e. Income (earnings + welfare benefits) & -0.0592 & 0.0414 & -0.0430 & 0.0365 \\
\hline
\end{tabular}

II. Parameter estimates total treatment effect with fake treatment municipalities

\begin{tabular}{lcc|rr}
\hline a. Time to (part-time) employment & 0.8080 & 0.9922 & 0.6141 & 0.3397 \\
b. Outflow from welfare & $-1.2838^{*}$ & 0.7346 & 0.1846 & 0.2305 \\
c. Earnings & 0.0156 & 0.0743 & 0.0400 & 0.0489 \\
d. Welfare benefits & -0.0002 & 0.0615 & -0.0563 & 0.0416 \\
e. Income (earnings + welfare benefits) & 0.0154 & 0.0529 & -0.0162 & 0.0331 \\
\hline
\end{tabular}

Note: Earnings, welfare benefits and income in $€ 1000$ per month. Natives are defined as native Dutch or Western immigrants. 
Figure 1: Budget constraint with and without earnings disregard

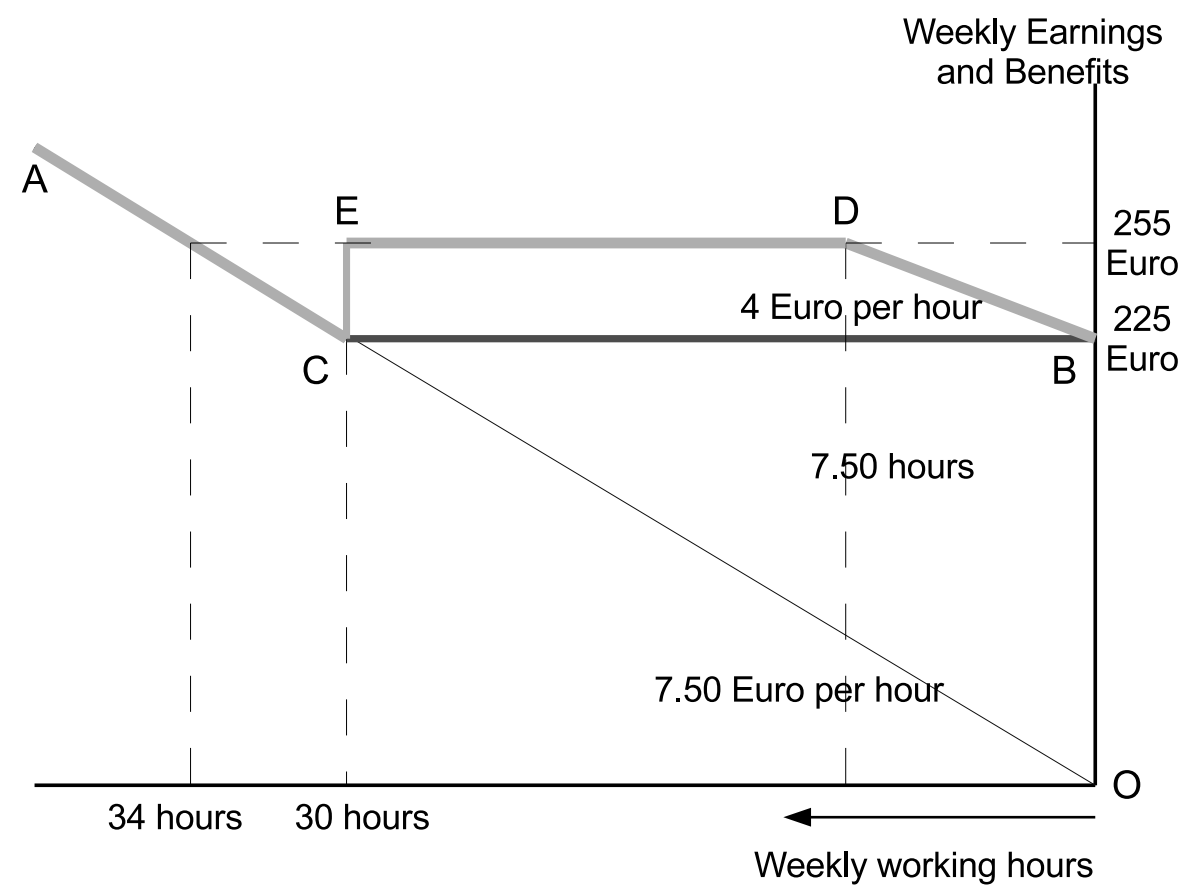


Figure 2: Yearly inflow of single mothers in welfare (start of new spells)

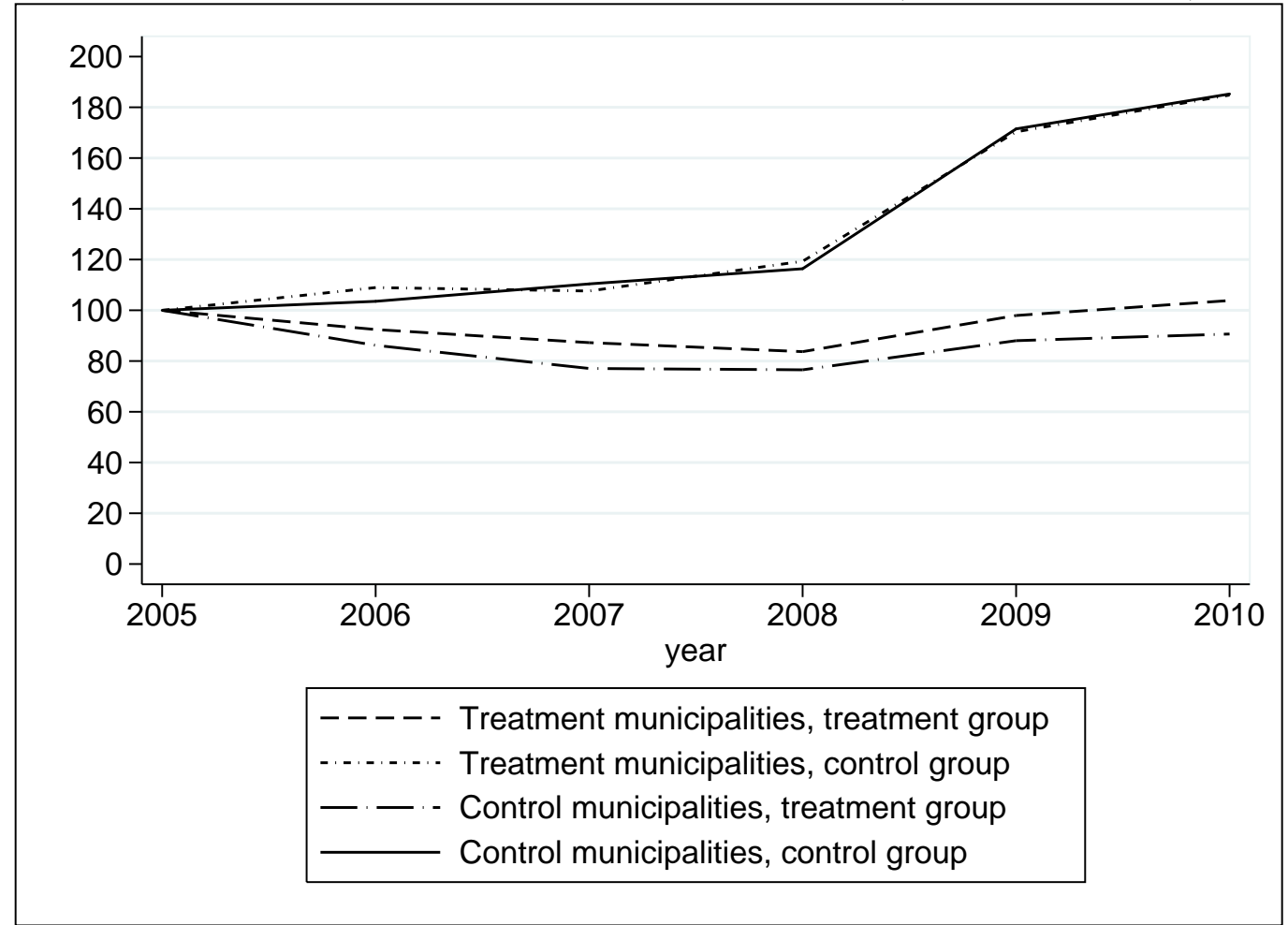

Note: 2005 is the base year. Treatment municipality $=$ municipality that implemented the instruments; control municipality $=$ all other Dutch municipalities; treatment group $=$ single mothers with children younger than 12 years; control group $=$ single mothers with all children 12 years or older. 
Figure 3: Share of single mothers that start working in combination with welfare Inflow curves and first differences

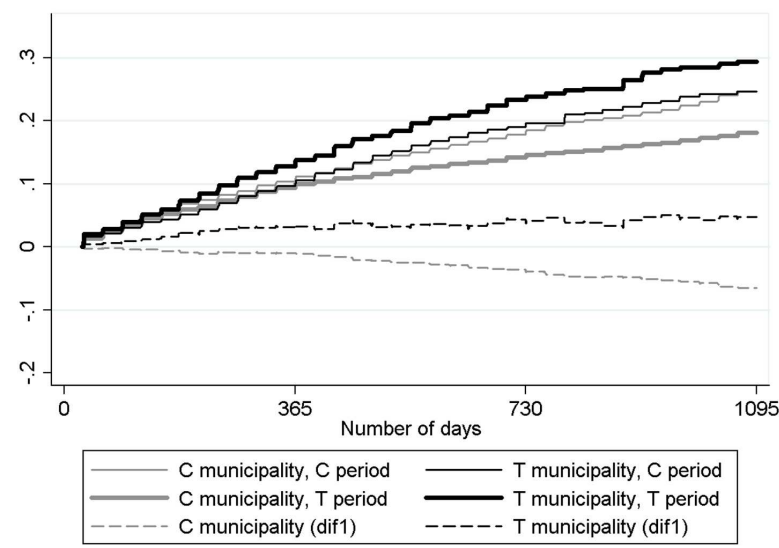

(a) Treatment group (immigrants)

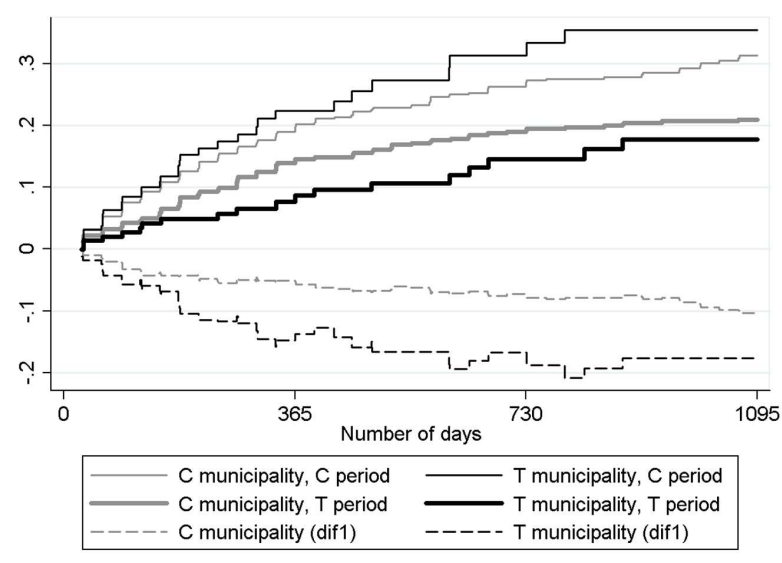

(b) Control group (immigrants)

Double and triple differences

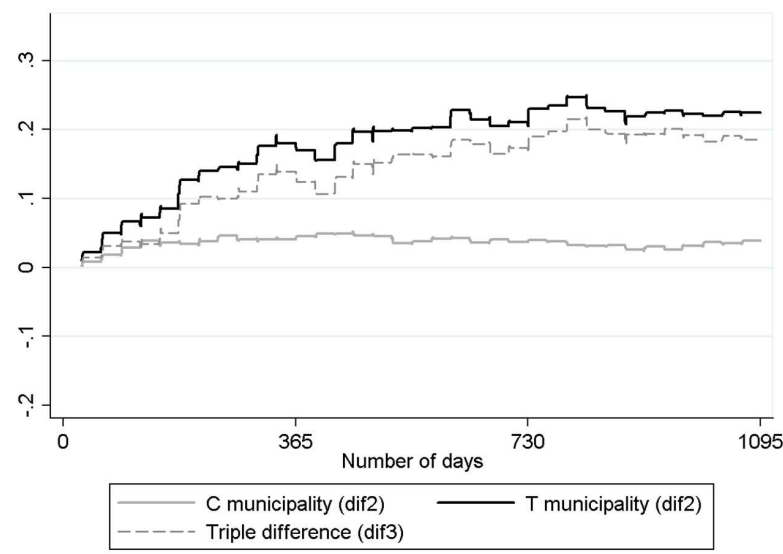

(c) Treatment effect (immigrants)

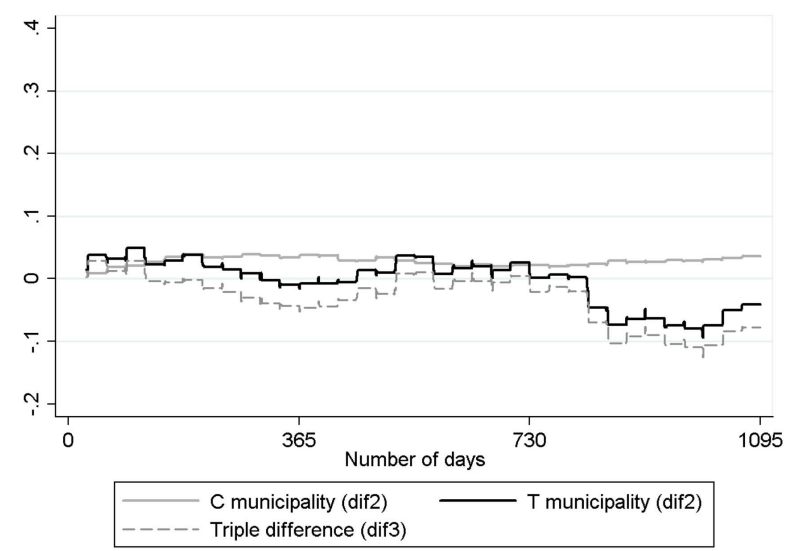

(d) Treatment effect (natives)

Note: Figures (a) and (b) show graphs for the inflow into part-time work. At $t=0$ a welfare spell starts and the graphs show the share of single mothers that started working over the duration of their welfare benefit spell. In addition, (a) and (b) show first differences, that present the increase or decrease in the share of single mothers that started working between the treatment and control period, for the treatment group and the control group in the treatment municipalities and control municipalities. Figures (c) and (d) present double and triple differences. The double differences show us to what degree the increase in the inflow to work was higher in the treatment than the the control group. Finally, we correct the double difference estimates of the treatment municipalities for the double differences found in the control municipalities. This leads to triple difference estimates of the treatment effects. 
Figure 4: Outflow from welfare Outflow curves and first differences

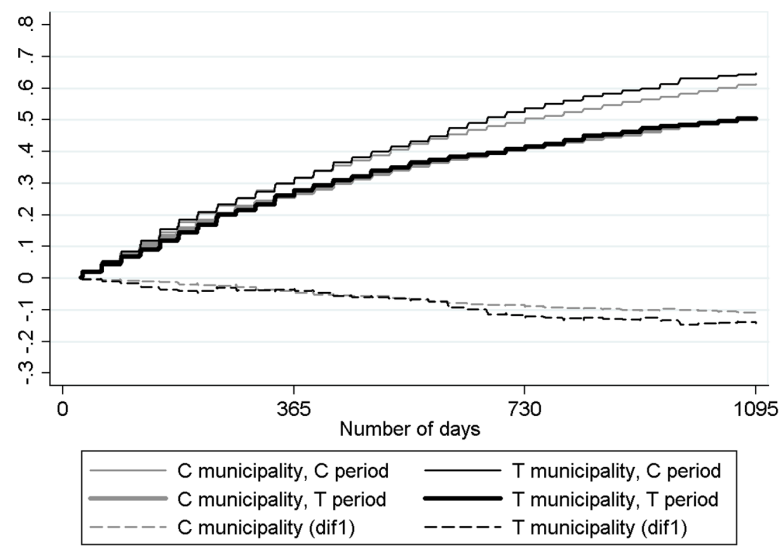

(a) Treatment group (immigrants)

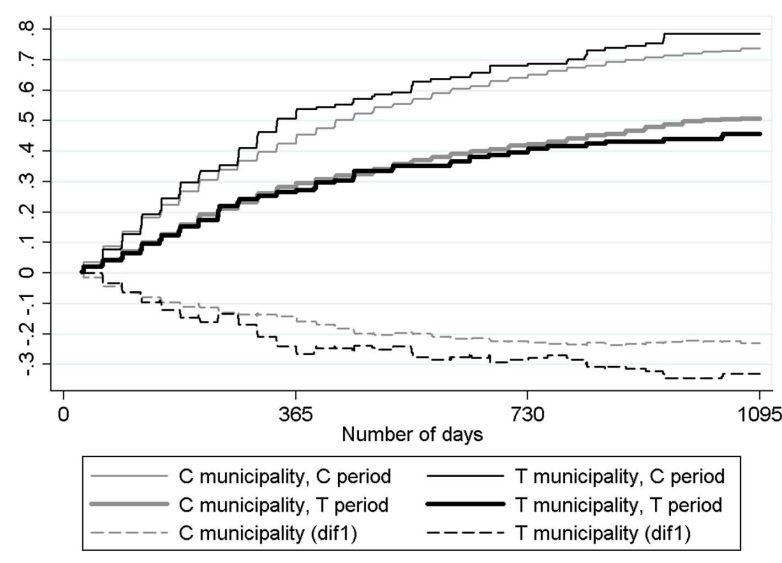

(b) Control group (immigrants)

Double and triple differences

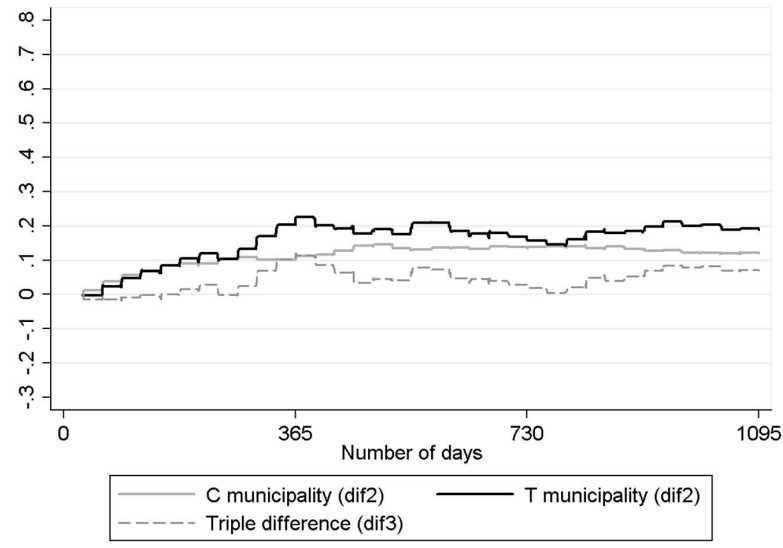

(c) Treatment effect (immigrants)

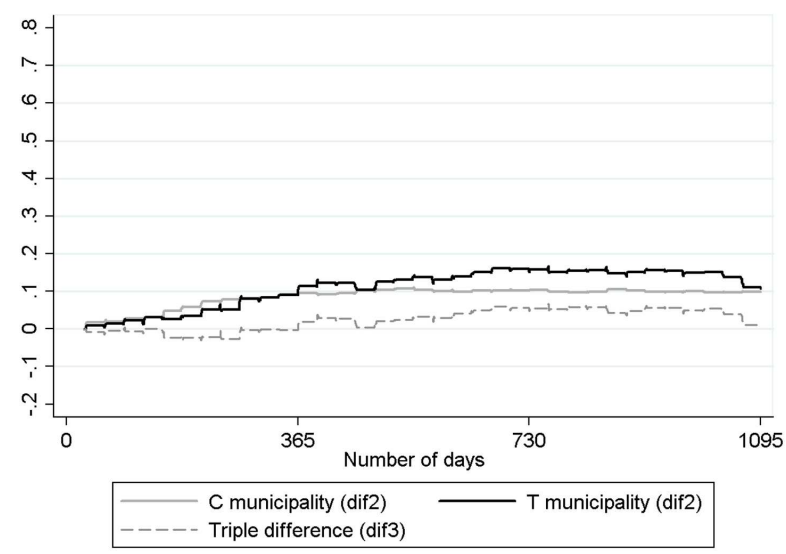

(d) Treatment effect (natives)

Note: Figures (a) and (b) show graphs for the outflow from welfare. At $t=0$ a welfare spell starts and the graphs show the share of single mothers that left welfare over the duration of their welfare benefit spell. In addition, (a) and (b) show first differences, that present the increase or decrease in the share of single mothers that left welfare between the treatment and control period, for the treatment group and the control group in the treatment municipalities and control municipalities. Figures (c) and (d) present double and triple differences. The double differences show us to what degree the increase in the outflow from welfare was higher in the treatment than the the control group. Finally, we correct the double difference estimates of the treatment municipalities for the double differences found in the control municipalities. This leads to triple difference estimates of the treatment effects. 
Figure 5: Distribution income from other sources

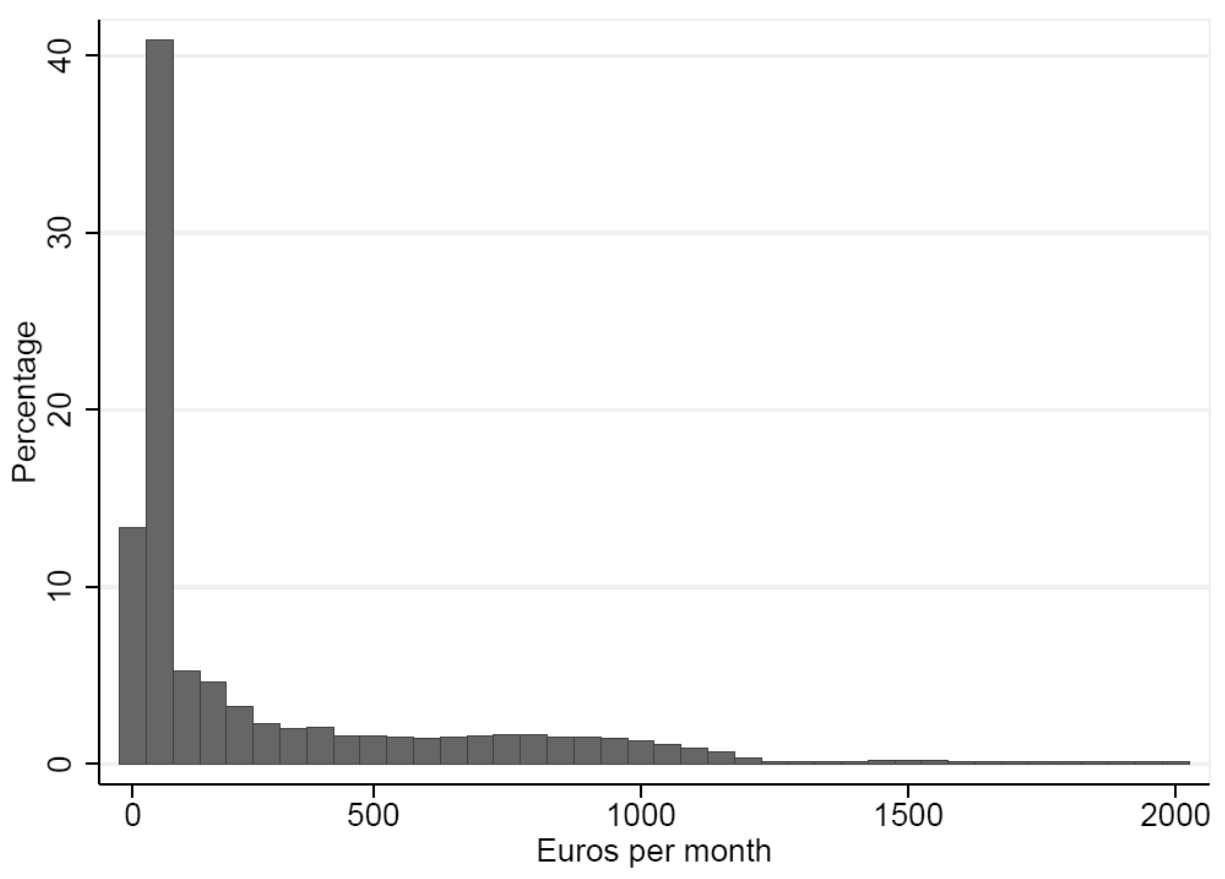




\section{A Extended figures}

Figure A.1: Inflow, outflow, and first differences for natives Inflow into part-time work

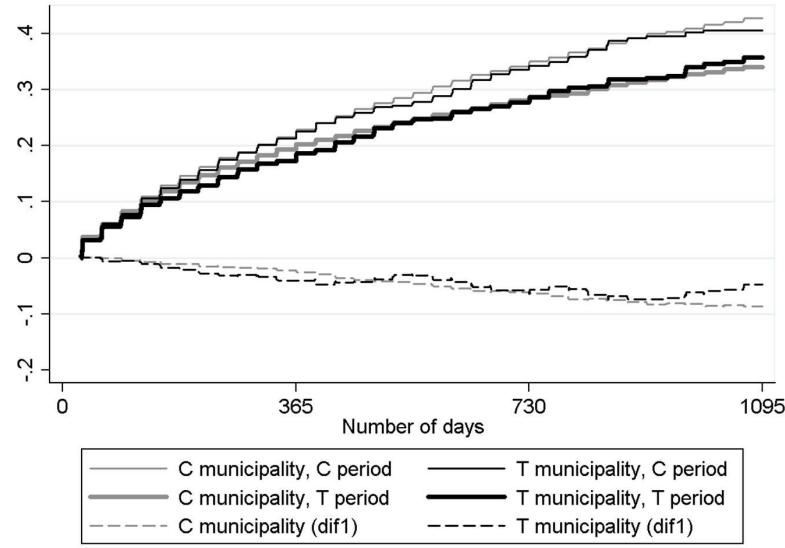

(a) Treatment group

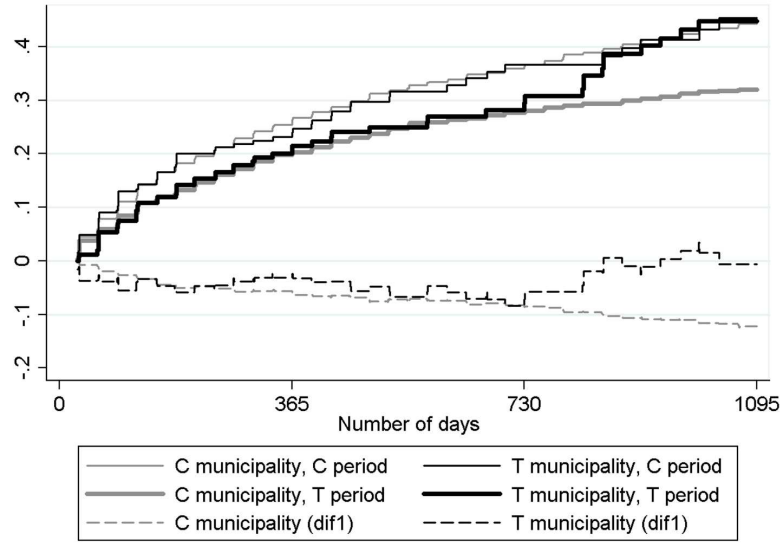

(b) Control group

$\underline{\text { Outflow from welfare }}$

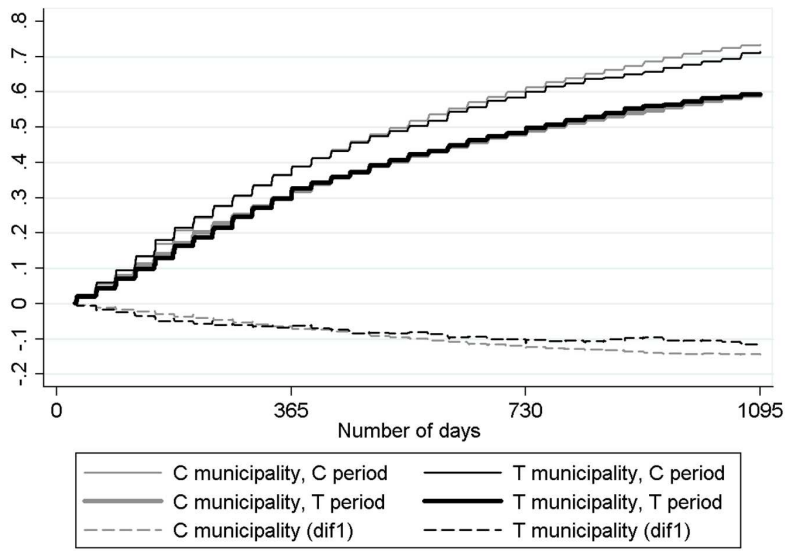

(c) Treatment group

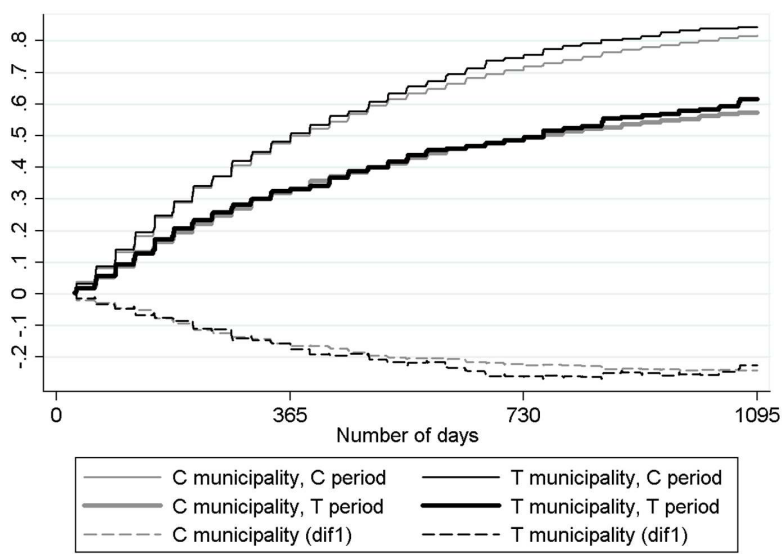

(d) Control group 


\section{B Extended estimation results}

Table B.1: Time to employment and outflow from welfare

\begin{tabular}{|c|c|c|c|c|c|c|c|c|}
\hline \multirow[b]{3}{*}{ Variable } & \multicolumn{4}{|c|}{ Time to part-time employment } & \multicolumn{4}{|c|}{ Outflow from welfare } \\
\hline & Immigrants & & Natives & & Immigrant & & Natives & \\
\hline & Coeff. & S.E. & Coeff. & S.E. & Coeff. & S.E. & Coeff. & S.E. \\
\hline $\mathrm{G}$ & -0.073 & 0.116 & -0.035 & 0.069 & -0.011 & 0.077 & 0.053 & 0.037 \\
\hline $\mathrm{M} \cdot \mathrm{G}$ & -0.107 & 0.241 & 0.007 & 0.177 & -0.129 & 0.150 & -0.020 & 0.084 \\
\hline $\mathrm{T}$ & $-0.564^{* * *}$ & 0.111 & $-0.429 * * *$ & 0.068 & $-0.853^{* * *}$ & 0.074 & $-0.819^{* * *}$ & 0.035 \\
\hline $\mathrm{M} \cdot \mathrm{T}$ & $-0.975^{*}$ & 0.560 & 0.212 & 0.283 & -0.254 & 0.272 & 0.179 & 0.142 \\
\hline $\mathrm{G} \cdot \mathrm{T}$ & $0.190^{*}$ & 0.113 & $0.182^{* * *}$ & 0.068 & $0.398^{* * *}$ & 0.074 & $0.276^{* * *}$ & 0.036 \\
\hline $\mathbf{G} \cdot \mathbf{M} \cdot \mathbf{T}$ & $1.778^{* * *}$ & 0.575 & -0.130 & 0.310 & 0.237 & 0.290 & -0.120 & 0.158 \\
\hline Welfare $30-60$ days & 0.046 & 0.105 & -0.025 & 0.057 & 0.047 & 0.101 & 0.065 & 0.059 \\
\hline Welfare $61-90$ days & $-0.359^{* * *}$ & 0.108 & $-0.288^{* * *}$ & 0.057 & $0.263^{* * *}$ & 0.095 & $0.377^{* * *}$ & 0.055 \\
\hline Welfare $91-180$ days & $-0.270^{* * *}$ & 0.095 & $-0.390 * * *$ & 0.052 & 0.105 & 0.088 & $0.592^{* * *}$ & 0.050 \\
\hline Welfare $181-365$ days & $-0.510^{* * *}$ & 0.094 & $-0.754^{* * *}$ & 0.054 & -0.071 & 0.087 & $0.576^{* * *}$ & 0.050 \\
\hline Welfare $366-730$ days & $-0.739 * * *$ & 0.099 & $-1.018^{* * *}$ & 0.060 & $-0.292^{* * *}$ & 0.089 & $0.402^{* * *}$ & 0.052 \\
\hline Welfare $>730$ days & $-0.998^{* * *}$ & 0.108 & $-1.303^{* * *}$ & 0.073 & $-0.559 * * *$ & 0.094 & $0.125^{* *}$ & 0.059 \\
\hline Age & $0.157^{* * *}$ & 0.021 & $0.070^{* * *}$ & 0.012 & $-0.043^{* * *}$ & 0.012 & -0.001 & 0.007 \\
\hline $\mathrm{Age}^{2}$ & $-0.002^{* * *}$ & 0.000 & $-0.001^{* * *}$ & 0.000 & $0.000^{* *}$ & 0.000 & $0.000 * * *$ & 0.000 \\
\hline Age youngest child & $0.067^{* * *}$ & 0.017 & $0.051^{* * *}$ & 0.011 & $-0.079 * * *$ & 0.010 & $-0.014^{* *}$ & 0.006 \\
\hline Age youngest child ${ }^{2}$ & -0.001 & 0.001 & $-0.002^{* *}$ & 0.001 & $0.007^{* * *}$ & 0.001 & $0.004^{* * *}$ & 0.000 \\
\hline \# Children & $-0.124^{* * *}$ & 0.020 & $-0.121^{* * *}$ & 0.015 & $-0.033^{* * *}$ & 0.012 & $-0.056^{* * *}$ & 0.008 \\
\hline Unmarried & $0.298^{* * *}$ & 0.043 & -0.014 & 0.027 & $-0.069^{* *}$ & 0.027 & $-0.251^{* * *}$ & 0.016 \\
\hline Widow & -0.104 & 0.197 & $-0.707^{* *}$ & 0.274 & -0.004 & 0.120 & 0.081 & 0.101 \\
\hline First gen. immigrant & $-0.331 * * *$ & 0.053 & & & $-0.153^{* * *}$ & 0.033 & & \\
\hline Western immigrant & & & $-0.143^{* * *}$ & 0.032 & & & $-0.097 * * *$ & 0.017 \\
\hline Alimony & $0.521^{* * *}$ & 0.064 & $0.387^{* * *}$ & 0.027 & $0.243^{* * *}$ & 0.043 & $-0.408 * * *$ & 0.019 \\
\hline Homeowner & 0.209 & 0.152 & & & $0.294^{* * *}$ & 0.097 & $0.213^{* * *}$ & 0.033 \\
\hline Constant & $-10.256^{* * *}$ & 0.393 & $-7.809^{* * *}$ & 0.228 & $-5.754^{* * *}$ & 0.234 & $-6.425^{* * *}$ & 0.129 \\
\hline$\alpha$ & $0.418^{* * *}$ & 0.148 & $0.231^{* * *}$ & 0.084 & 0.062 & 0.062 & $0.065^{* * *}$ & 0.023 \\
\hline \# Individuals & 20020 & & 30172 & & 22150 & & 40132 & \\
\hline
\end{tabular}

Note: $\mathrm{G}=$ target group, $\mathrm{M}=$ treatment municipality, $\mathrm{T}=$ treatment period, $\mathrm{P}=$ treatment municipality with job creation. In this model we also included year dummies, treatment municipality dummies, dummies indicating the cause of welfare, and correction terms for treatment municipalities with a reemployment bonus. Unfortunately we do not have information about reemployment bonuses in control municipalities. However, for all treatment municipalities we know whether and in which years they provided reemployment bonuses to the control group and the treatment group. To correct for this we include interactions of year and the provision of a reemployment bonus (yes=1, no=0). In addition, we allow these effect to be different for the treatment and the control group. Finally, natives are defined as native Dutch or Western immigrants. 
Table B.2: Earnings and Welfare Benefits

\begin{tabular}{|c|c|c|c|c|c|c|c|c|c|c|c|c|}
\hline \multirow[b]{3}{*}{ Variable } & \multicolumn{4}{|l|}{ Earnings } & \multicolumn{4}{|c|}{ Welfare benefits } & \multicolumn{4}{|c|}{ Earnings + Benefits } \\
\hline & Immigrants & & Natives & & Immigrants & & Natives & & Immigrants & & Natives & \\
\hline & Coeff. & S.E. & Coeff. & S.E. & Coeff. & S.E. & Coeff. & S.E. & Coeff. & S.E. & Coeff. & S.E. \\
\hline $\mathrm{G}$ & $-19.15^{*}$ & 9.88 & -9.54 & 8.09 & 14.26 & 8.86 & -1.06 & 7.37 & -4.89 & 6.27 & $-10.61^{*}$ & 5.45 \\
\hline $\mathrm{M} \cdot \mathrm{G}$ & 2.25 & 31.86 & -8.20 & 24.74 & -1.99 & 28.23 & 9.07 & 21.33 & 0.26 & 18.13 & 0.87 & 17.21 \\
\hline $\mathrm{T}$ & $-62.73^{* * *}$ & 10.75 & -2.57 & 7.60 & $71.29^{* * *}$ & 10.00 & $143.20^{* * *}$ & 6.91 & 8.57 & 7.81 & $140.62^{* * *}$ & 5.53 \\
\hline $\mathrm{M} \cdot \mathrm{T}$ & $-89.35^{* * *}$ & 30.80 & $-75.33^{* * *}$ & 28.23 & $64.62^{* *}$ & 28.71 & 21.33 & 26.76 & -24.74 & 21.44 & $-54.01^{* *}$ & 22.95 \\
\hline $\mathrm{G} \cdot \mathrm{T}$ & $31.15^{* * *}$ & 9.50 & $20.12^{* * *}$ & 7.37 & $-53.56^{* * *}$ & 8.58 & $-40.50 * * *$ & 6.57 & $-22.41 * * *$ & 5.78 & $-20.38 * * *$ & 4.88 \\
\hline $\mathbf{G} \cdot \mathbf{M} \cdot \mathbf{T}$ & $95.22^{* * *}$ & 32.60 & $62.31^{* *}$ & 31.14 & $-50.76^{*}$ & 29.86 & -35.09 & 29.40 & $44.46^{* *}$ & 22.50 & 27.22 & 24.27 \\
\hline Welfare $30-60$ days & $-17.45^{* * *}$ & 5.79 & $-10.80^{* *}$ & 5.03 & $-26.80^{* * *}$ & 7.40 & $-25.41^{* * *}$ & 5.48 & $-44.24^{* * *}$ & 8.49 & $-36.21^{* * *}$ & 6.88 \\
\hline Welfare $61-90$ days & $-36.34^{* * *}$ & 4.33 & $-26.07 * * *$ & 3.70 & $-134.04^{* * *}$ & 5.88 & $-82.32^{* * *}$ & 4.23 & $-170.37^{* * *}$ & 6.74 & $-108.39 * * *$ & 5.33 \\
\hline Welfare 91-180 days & $-85.05^{* * *}$ & 4.63 & $-97.26^{* * *}$ & 3.93 & $-206.98^{* * *}$ & 6.08 & $-180.22^{* * *}$ & 4.45 & $-292.03^{* * *}$ & 7.02 & $-277.48^{* * *}$ & 5.64 \\
\hline Welfare $181-365$ days & $-87.89^{* * *}$ & 4.88 & $-105.30^{* * *}$ & 4.18 & $-207.93^{* * *}$ & 6.20 & $-190.94^{* * *}$ & 4.61 & $-295.82^{* * *}$ & 7.16 & $-296.24^{* * *}$ & 5.76 \\
\hline Welfare $366-730$ days & $-99.94^{* * *}$ & 5.12 & $-122.47^{* * *}$ & 4.47 & $-184.34^{* * *}$ & 6.29 & $-160.72^{* * *}$ & 4.80 & $-284.29^{* * *}$ & 7.15 & $-283.19^{* * *}$ & 5.78 \\
\hline Welfare longer than 730 days & $-107.72^{* * *}$ & 5.40 & $-133.84 * * *$ & 4.79 & $-148.65^{* * *}$ & 6.29 & $-114.55^{* * *}$ & 4.87 & $-256.37^{* * *}$ & 6.85 & $-248.39 * * *$ & 5.47 \\
\hline Age & $21.71^{* * *}$ & 1.71 & $26.91^{* * *}$ & 1.69 & $17.15^{* * *}$ & 1.85 & $17.82^{* * *}$ & 1.71 & $38.86^{* * *}$ & 1.43 & $44.74^{* * *}$ & 1.36 \\
\hline $\mathrm{Age}^{2}$ & $-0.24^{* * *}$ & 0.02 & $-0.32^{* * *}$ & 0.02 & $-0.24^{* * *}$ & 0.03 & $-0.24^{* * *}$ & 0.02 & $-0.48^{* * *}$ & 0.02 & $-0.56^{* * *}$ & 0.02 \\
\hline Age youngest child & $2.31^{*}$ & 1.22 & $4.73^{* * *}$ & 1.33 & -1.21 & 1.14 & $-7.51^{* * *}$ & 1.20 & 1.10 & 0.83 & $-2.78^{* * *}$ & 0.91 \\
\hline Age youngest child ${ }^{2}$ & 0.08 & 0.10 & -0.14 & 0.10 & $-0.29 * * *$ & 0.10 & 0.01 & 0.09 & $-0.21^{* * *}$ & 0.07 & $-0.13^{* *}$ & 0.07 \\
\hline \# Children & $-18.21^{* * *}$ & 1.51 & $-31.19 * * *$ & 1.91 & $8.90^{* * *}$ & 1.35 & $16.06^{* * *}$ & 1.70 & $-9.31^{* * *}$ & 0.89 & $-15.13^{* * *}$ & 1.17 \\
\hline Unmarried & $7.95^{* *}$ & 3.75 & $-21.62^{* * *}$ & 4.08 & $6.27^{*}$ & 3.27 & $24.64^{* * *}$ & 3.54 & $14.22^{* * *}$ & 2.08 & 3.02 & 2.18 \\
\hline Widow & 32.20 & 22.03 & 34.75 & 35.35 & $-35.01^{*}$ & 19.80 & -37.26 & 31.85 & -2.81 & 8.67 & -2.51 & 12.15 \\
\hline First generation immigrant & $-21.48^{* * *}$ & 4.66 & & & 6.73 & 4.30 & & & $-14.74^{* * *}$ & 3.14 & & \\
\hline Western immigrant & & & $-33.63^{* * *}$ & 4.53 & & & $24.69^{* * *}$ & 3.98 & & & $-8.94^{* * *}$ & 2.51 \\
\hline Alimony & $243.02^{* * *}$ & 7.15 & $227.70^{* * *}$ & 3.84 & $-177.57^{* * *}$ & 6.22 & $-153.95^{* * *}$ & 3.40 & $65.46^{* * *}$ & 4.20 & $73.76^{* * *}$ & 2.26 \\
\hline Homeowner & $42.63^{* *}$ & 16.80 & $17.74^{*}$ & 9.06 & $-41.45^{* * *}$ & 14.50 & -11.26 & 7.84 & 1.19 & 10.86 & 6.48 & 5.84 \\
\hline Constant & $-110.54^{* * *}$ & 29.94 & $-103.05^{* * *}$ & 29.47 & $807.19^{* * *}$ & 33.34 & $602.83^{* * *}$ & 30.33 & $696.65^{* * *}$ & 27.54 & $499.78^{* * *}$ & 25.32 \\
\hline \# Individuals & 22177 & & 38614 & & 22177 & & 38614 & & 22177 & & 38614 & \\
\hline
\end{tabular}

Note: $\mathrm{G}=$ target group, $\mathrm{M}=$ treatment municipality, $\mathrm{T}=$ treatment period, $\mathrm{P}=$ treatment municipality with job creation. In this model we also included year dummies, treatment municipality dummies, dummies indicating the cause of welfare, and correction terms for treatment municipalities with a reemployment bonus. Unfortunately we do not have information about reemployment bonuses in control municipalities. However, for all treatment municipalities we know whether and in which years they provided reemployment bonuses to the control group and the treatment group. To correct for this we include interactions of year and the provision of a reemployment bonus (yes=1, no=0). In addition, we allow these effect to be different for the treatment and the control group. We only take into account observations for which welfare benefits and earnings are lower than $€ 2000$ per month. Finally, natives are defined as native Dutch or Western immigrants. 